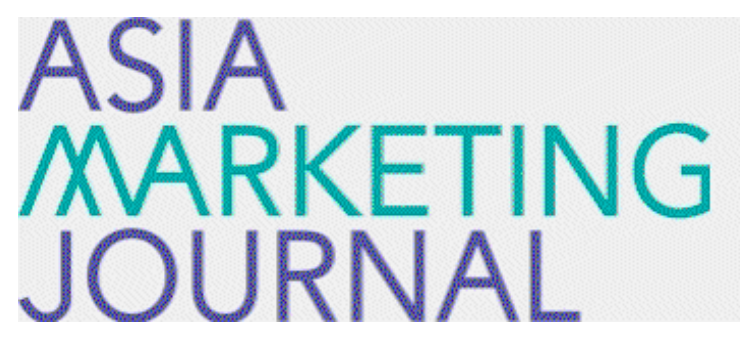

ASIA MARKETING JOURNAL

Volume 10 | Issue 2

Article 1

7-30-2008

\title{
해외 복수 시장 진출 기업의 제품 매출 이륙 시점 예촉 모형에 관한 연구
}

Jai Hak Chung

Ho Kyung Chung

Follow this and additional works at: https://amj.kma.re.kr/journal

Part of the Marketing Commons

\section{Recommended Citation}

Chung, Jai Hak and Chung, Ho Kyung (2008) "해외 복수 시장 진출 기업의 제품 매출 이륙 시점 예측 모형에 관한 연 구," Asia Marketing Journal: Vol. 10 : Iss. 2 , Article 1.

Available at: https://doi.org/10.53728/2765-6500.1212

This Article is brought to you for free and open access by Asia Marketing Journal. It has been accepted for inclusion in Asia Marketing Journal by an authorized editor of Asia Marketing Journal. 


\title{
해외 복수 시장 진출 기업의 \\ 제품 매출 이륙 시점 예측 모형에 관한 연구*
}

\section{An Exploratory Study on Forecasting Sales Take-off Timing for Products in Multiple Markets*}

\author{
정 재 학(Chung, Jaihak)** \\ 정 호 경(Chung, Hokyung)***
}

본 연구는 해외 여러 시장에서 제품을 판매하는 글로벌 기업의 입장에서 복수 시장에서 발생하는 제품 수준의 매출 이륙 시점을 예측할 수 있는 모형을 제시하였다. 이 모형을 이용하여 복수 시장 정 보, 제품 속성 정보, 가격 정보, 매출 정보 중 매출 이륙 시점 예측에 유용한 설명 변수들을 규명하기 위해 국내 전자 업체가 2년 5개월간 10 개국 시장에 판매한 90 종류의 PDP TV, LCD TV들 월별 매 출 자료들을 대상으로 실증 분석을 하였다. 분석 결과, 매출 이륙 시점 예측에 유용한 변수들을 다음 과 같이 파악할 수 있었다.

첫째, 대상 제품이 표적 시장에 진출하기 이전에 진출한 타 시장에서의 매출 자료를 표적 시장에서 의 대상 제품 매출 이륙 시점 예측에 이용하는 것이 가장 중요함을 실증 분석을 통해 알 수 있었다. 특히, 매출 이륙 시점 예측에 동일 제품의 타 시장 혁신 계수를 이용하는 것이 유용한 반면, 동일 제 품의 타 시장 모방 계수는 예측력에 도움을 주지 못함을 알 수 있었다. 둘째, 타 제품의 표적 시장 확산 정보는 예상과 달리 대상 제품의 표적 시장에서의 매출 이륙 시점 예측에 기여하는 바는 낮음 을 알 수 있었다. 셋째, 일반적 인식처럼 가격과 제품의 속성도 이륙시점의 발생 시기에 영향을 미치 는 것을 알 수 있었다. 하지만 제품의 자체 가격 정보 보다 시장 평균 가격 대비 대상 제품 가격 비 율이 매출 이륙 시점 예측에 보다 효과적임을 알 수 있었다. 마지막으로, 전기 누적 매출량 역시 $\mathrm{PLC}$ 중 초기 시점을 예측하는 상황임에도 불구하고 제품 수준의 매출 이륙 시점 예측에 중요한 변 수임을 알 수 있었다. 본 연구에서 제시한 매출 이륙 시점 예측 모형은 평균치에 근거한 일반적 예측 과 비교해 볼 때 높은 예측력을 보여 주었다. 본 연구에서 제시한 예측 모형을 이용할 경우 특히 예 측 시점이 2기일 때 가장 높음을 알 수 있었다.

\footnotetext{
* 본 연구의 실증 분석에 필요한 자료를 제공한 국내 전자업체 $\mathrm{K}$ 에게 감사를 드립니다. 제공 업체의 보안 요구에 따라 분석 내용 일부와, 지역 명칭 및 제품 명이 변경되었음을 알립니다. 또한, 적절한 지적과 제안으로 본 연구를 개선하는 데 큰 도움을 주신 익명의 두 분 심사자께도 깊은 감사를 드립니다.

** 서강대학교 경영대학 부교수(jaihak@sogang.ac.kr)

**** 대림산업(hkjung@sogang.ac.kr)
} 
본 연구 결과가 기여하는 바를 보면 첫째, 기존 확산모형과 달리 본 연구에서는 제품의 매출 초기 시점인 매출 이륙 시점을 측정하고, 예측하는 모형을 제시하였다. 둘째, 본 연구는 글로벌 시장에서 적용 가능한 제품 수준의 매출 이륙 시점을 예측하였다. 셋째, 본 연구는 처음으로 매출 이륙 시점 예측력을 예측 시점 별로 분석하여 모형의 예측력을 이해하는 데 새로운 접근법을 제시하였다.

핵심개념: 제품 생명 주기(PLC), 시장 전환 시점(Market Turning Point), 매출 이륙 시점(Sales Take-off Timing), 글로벌시장, Bass 모형, 시장 혁신 계수, 시장 모방 계수

\section{I. 서 론}

최근 들어 국내 기업들은 빠른 속도로 해외 시장에 진출하고 있다. 특히 삼성전자나 $\mathrm{LG}$ 전 자와 국내 대표 전자 업체들은 이미 미국 시장 만이 아니라 유럽 각 국과 아시아의 수많은 시 장에 진입하여 성공적으로 자리를 잡은 상태이 다. 전자 업체만이 아니라 요즘은 화장품, 제과, 생활용품, 영화 등과 같은 다양한 산업에서 활 동하고 있는 국내 기업체들도 해외 시장으로 급격하게 진출하여 시장을 보다 다각화하고 있 다. 이렇게 국내 기업들이 해외 여러 시장에 진 입해 지속적으로 제품을 출시하는 경우가 많아 짐에 따라 이제 국내 기업의 마케팅 관리자가 해결해야 새로운 주요 의사 결정 과제 중 하나 는 자사의 특정 제품이 해외의 여러 시장에서 판매될 경우, 언제 어느 시장에 집중적으로 마 케팅자원을 할당할 것 인지를 시간에 따라 계 획하는 것이다. 최근 전자업체들은 제품 생명 주기 관리를 위해 많은 노력을 해오고 있다. 예 를 들어 최근 삼성전자는 특정 기업의 입장에 서 개별 제품의 $\mathrm{PLC}$ 관리를 향후 해결해야 할 핵심 역량 과제로 선정하여 전사적인 차원에서
이를 관리할 PLC 관리 부서를 국내 기업으로 는 처음으로 만들었으며 SDS와의 협업을 통해 제품 수명 관리 시스템을 도입하고 있다(한국 경제신문 2007).

제품 생명 주기에 따른 제품 관리에 있어 핵 심 과제는 신시장에 자사 제품을 출시 후, 매출 극대화, 수익 극대화, 그리고 제품 단종을 위한 계획을 사전에 수립하는 것이다. 성공적인 계획 수립을 위해 마케팅 관리자가 필요로 하는 것 은 자사 제품이 시장에 진출 후 본격적인 성장 시점, 매출 한계에 도달하는 시점, 그리고 제품 을 시장에서 철수해야 할 시점과 같은 주요 전 환시점(turning point)을 사전에 예측하는 작업 이다. 하지만 생명 주기상의 주요 전환 시점에 대한 연구는 매우 부족한 상태이다. 마케팅 관 리자가 제품 출시 후 제품의 매출 곡선 상에 존재하는 주요 전환시점 중 사전에 알고 싶어 하는 시점은 다음 〈그림 1〉에서 예시한 5가지 이다.

제품 생명 주기상 주요한 첫 번째 전환 시점 (turning point)은 제품을 시장에 처음으로 출 시하는 시점(Launching time 또는 Time-tomarket)이다. 제품 출시 시점은 시장 환경, 판 매사의 계획 또는 전략, 제조사의 전략에 의해 
〈그림 1〉 주요 전환 시점

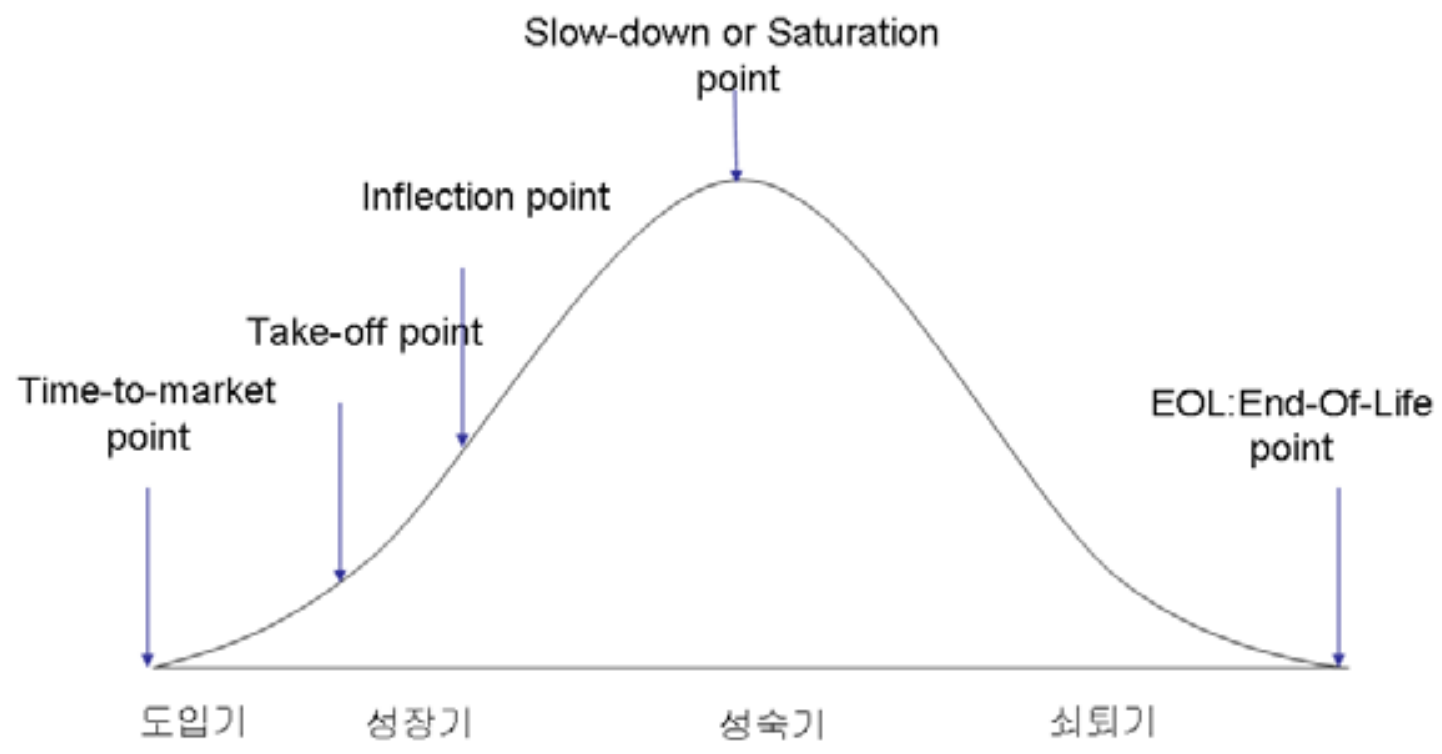

모두 영향을 받을 수 있다. 두 번째 시점은 제 품 수명 주기(PLC)의 도입기에서 성장기로 전 환(transition)이 이루어지는 매출 이륙 시점 (take-off timing)이다. 시장 출시 후 본격적으 로 시장에서 받아들여지기 시작하는 이 시점에 제품의 매출 곡선의 기울기 변화율이 가장 높 아진다. 마케팅 관리자는 이 시점에 도달해야 제품이 시장에 성공적으로 자리 잡기 시작했음 을 알게 되는 중요한 시점이며 또한 이때부터 본격적으로 많은 마케팅 자원을 투입하게 되므 로 이 시점을 사전에 알 수 있다면 시간에 따 른 마케팅 자원 할당 계획 수립에 도움이 될 수 있을 것이다. 세 번째 시점은 제품이 매출 이륙 시점을 지난 후 매출 증가율이 점차 높아 지다가 둔화되는 변곡 시점(inflection timing) 이다. 이 시점에 일반적으로 시장의 주 고객층 이 혁신 고객층이나 얼리 어답터 고객층에서 일반 소비자 고객층으로 전환되는 시점이며 본
격적으로 제품이 대중화됨을 알리는 시점이므 로 마케팅 담당자에게는 특별한 의미를 갖게 된다. 변곡 시점까지 제품은 소비자들에게 새로 운 제품으로 인식되며 신선한 제품으로서 시장 에 매우 빠른 속도로 확산되나 변곡 시점에 도 달한 이후에는 매출 증가율이 감소하기 시작하 게 된다. 네 번째 시점은 매출이 증가세를 멈추 고 정체, 또는 감소하기 시작하는 쇠퇴 시점 (saturation timing)이다. 제품 매출이 이 시점 에 가까워지면 기업은 시장 점유율보다는 수익 증대에 보다 많은 노력을 기울이게 되며, 동일 제품으로 시장 활성화를 위한 활동이나 그 제 품을 대체하는 신제품의 출시를 본격적으로 준 비하게 된다. 마지막으로 다섯 번째 시점은 제 품 매출이 발생하지 않는 즉, 제품이 시장에서 사라지는 단종 시점(EOL timing: End-Of-Life timing)이다. 이 시점을 결정하는 것은 시장보 다는 기업의 의지와 상황에 의해 크게 좌우되 
기에 시장 전환점 예측 관점에서 상대적으로 중요도가 덜하다.

마케팅 관리자의 입장에서 앞서 언급한 시장 전환시점들 중 어느 시점이 특히 중요한 지는 관련 산업과 제품의 특징에 따라 다를 수 있을 것이다. 본 연구에서는 사전 조사(Pilot study) 로 2007년 1월부터 2007년 9월까지 해외 시장 에 진출한 국내 7 개 업체 마케팅 또는 기획 업 무 담당자 326명을 대상으로 제품 출시 후 매 출 곡선상에 존재하는 전환 시점 중 어느 시점 을 예측하는 것이 가장 중요한 지에 대한 설문 조사를 실시하였다. 조사 결과, $38 \%$ 의 응답자 가 매출 이륙 시점(take-off timing)에 대한 예 측을 가장 중요하다고 응답했으며, 그 다음으로 $31 \%$ 의 응답자가 쇠퇴 시점(saturation timing) 에 대한 예측을, $23 \%$ 의 응답자들이 변곡 시점 (inflection timing)을, 마지막으로 $8 \%$ 의 응답자 들이 단종 시점(EOL timing) 예측에 관심을 보 였다. 이를 토대로 볼 때, 마케팅관리자들이 가 장 예측하고 싶어하는 제품 생명 주기상의 시 점은 자사의 특정 제품이 언제 각 시장에서 본 격적으로 확산될 지, 즉 제품 매출 곡선상에서 매출 이륙 시점(take-off timing)에 관한 예측 이다. 매출 이륙 시점이 제품 관리자에게 중요 한 이유는 다음과 같다. 첫째, 수요가 급격한 증가를 보이는 매출 이륙 시점에는 큰 폭의 수 요 증가에 대응하기 위해 광고, 생산, 재고, 유 통 및 영업원 관리가 매우 중요하다. 기업의 입 장에서는 볼 때 자사 제품의 특정 시장에서의 매출 이륙 시점을 예측할 수 있다면 복수의 시 장에 한정된 마케팅 자원을 할당하는 과정에서 향후 어떤 시점에 어떤 시장에 마케팅 자원을 집중해야 할 지를 계획하는 데 많은 도움이 될
것이다. 둘째, 글로벌 기업이 당면하는 전형적 인 문제 중 하나가 제품을 모든 시장에 동시에 출시하는 전략(Sprinkler strategy)을 채택할 것 인지 아니면 시장 별로 제품을 출시하는 시점을 달리하는 제품 출시 시점 차별화 전략(Waterfall strategy)을 채택할 것인지를 결정하는 것인데, 시장 별 출시 시점을 결정하는 데 있어 시장 별 매출 이륙 시점에 대한 정보는 매우 중요한 역 할을 한다(Kalish, Mahajan and Muller 1995).

학계에서도 제품 생명 주기(PLC: Product Lifecycle)은 중요한 개념으로 소개되고 있지만 정작 이를 관리하는 데 필요한 제품 매출 곡선 상의 이륙시점(take-off timing)에 대한 연구는 매우 부족한 상태이다. 이러한 상황을 인식해 마케팅 과학 학회(Marketing Science Institute) 에서도 PLC 관리와 매출 이륙 시점 연구를 가 장 우선 순위의 연구 주제 중 하나로 선정 하 였다(Marketing Science Institute 1995).

과거 80 년대에 많은 연구가 이루어진 확산 모 형(Diffusion Model)을 제품의 매출 이륙 시점 에 관한 예측에 기술적으로는 적용할 수 있으 나, 확산 모형들은 대부분 변곡 시점 이후의 매 출 자료를 이용해 생명 주기 후반의 매출 예측 을 하는 데 적합한 반면에 이륙 시점이 발생하 는 제품 생명 주기 초기의 매출 예측에는 효과 적이지 못하다(Golder and Telli 1997). 생명 주 기상의 주요 전환 시점 중 특히 초기에 발생하 는 시점인 매출 이륙 시점을 예측하기가 어려 운 가장 큰 이유는 매출 이륙 시점을 설명해 줄 수 있는 정보가 매우 제한되어 있기 때문이 다. 때문에 시장에서 이미 매출이 발생한 시점 이기는 하나 수요 예측 모형에 가장 중요한 사 전 매출 성과 정보가 부족하다 보니 과거 매출 
자료에만 의존한 일반적 확산 모형이나 시계열 모형(time-series model)을 그대로 사용하는 것 은 바람직하지 않다.

때문에 본 연구는 해외 여러 시장에 진출한 기업의 입장에서 개별 제품의 생명 주기 중 특 히 매출 이륙 시점 예측에 도움을 줄 수 있는 모형을 제시하고 어떤 정보가 매출 이륙 시점 예측에 도움이 되는지를 알기 위한 탐색적 연 구를 하고자 한다. 특히, 본 연구는 해외의 복 수 시장에서 제품을 판매하는 기업이 매출 이 륙 시점 예측을 위해 과거 매출 자료 이외에 활용할 수 있는 효과적인 설명변수가 무엇이고 이 들이 어느 정도 효과가 있는 지를 평가함으 로써 실무자들에게 도움을 주고자 한다. 이를 위해 본 연구는 보통 매출 이륙 시점 예측을 위해 크게 5 가지 유형의 변수들을 고려하였다. 즉, 일반적으로 수요 예측에서 고려되는 제품 속성, 가격, 매출과 더불어 글로벌 기업만이 복 수 시장에서 활동하며 얻을 수 있는 2가지 정 보를 설명 변수로 추가하였다. 해외 복수 시장 에 진출한 기업만이 대상 제품의 매출 자료 이 외에 활용할 수 있는 첫 번째 정보는 '표적 시 장의 신제품 확산 성향 정보이다. 대상 제품이 출시되기 이전에 표적 시장에서 출시된 타 제 품들의 시장 확산 정보가 특정 제품의 표적 시 장에서의 매출 이륙시점을 설명하는 데 유용한 지를 평가해 보고자 한다. 반면에 두 번째 설명 변수로 ‘타 시장의 제품 확산 성향 정보'의 효 과를 평가해 보고자 한다. 즉, 대상 제품이 표 적 시장이 아니라 다른 시장에서 이미 출시된 경우 타 시장에서 이미 발생한 매출 자료를 이
용해 타 시장의 제품 확산 정보를 이용하여 표 적 시장에서의 매출 이륙 시점을 예측하여 보 고, 그 효과를 평가해 보고자 한다.

본 연구는 매출 이륙 시점 예측과 설명 변수 와의 관계를 규명하기 위해 hazard 함수를 이 용해 모형을 개발하였고, 실증 분석은 2003년 1 월부터 2006년 5월까지 10 개국에서 판매된 $\mathrm{K}$ 전자업체 ${ }^{1}$ 의 $\mathrm{LCD}$ TV와 PDP TV 매출 자료 를 이용하였다. 분석 결과를 토대로 매출 이륙 시점 예측 모형의 적합도를 평가하였으며, 이를 이륙 시점 예측에 도움이 되는 설명변수에 대 한 영향 분석을 실시하였으며, 마지막으로 본 연구 결과의 의의와 향후 연구 방향을 제시하 였다.

본 연구는 모두 5 장으로 구성되어 있다. 제 1 장에서는 연구의 목적, 연구의 범위 및 연구의 방법을 제시하였다. 제 2장에서는 본 연구에서 제안된 변수에 대한 설명 및 연구모형에 대한 이론적 배경을 살펴보았다. 제 3장에서는 본 연 구의 모형에 대해서 제시하였고 제 4 장에서는 실증분석을 실행한 결과를 제시하였다. 제 5장 에서는 본 연구의 결론, 시사점 및 한계점과 향 후 연구방향을 제시하였다.

\section{II. 이론적 배경}

\section{1 제품 매출 이륙 시점 예측}

그 동안 PLC(Product Life Cycle: 제품 생명

1) 자료 제공 업체의 보안 요청에 따라 해당 업체의 이름은 익명으로 처리하였음 
주기)에 관한 연구는 다음 3 가지 관점에서 주 로 이루어져왔다. 첫째, 대부분의 제품 생명 주 기는 주로 시장 수준의 PLC를 다루어왔다 (Golder and Telli 1997, Mahajan, Muller, and Bass 1990). 둘째, 그 동안 제품 생명 주기 예 측은 대부분 확산 모형(Diffusion Model)에 관 한 것이었는 데 이 모형들은 시점 예측 보다는 시기별 매출량 예측을 위한 모형들이다. 이들 모형은 제품 생명 주기 상 변곡 시점을 지난 시점에서 향후 매출을 예측하는 데 바람직하기 에(Mahajan, Muller, and Bass 1990)본 연구에 서 다루고자 하는 매출 이륙 시점을 예측하는 데는 한계가 있다. 확산 모형은 기본적으로 과 거 시장 매출 자료에 의존하여 향후 시장 매출 을 예측하는 방식이므로 과거 시장 매출 자료 가 부족한 생명 주기 초기 시점에는 예측 정확 도가 떨어지는 구조적인 한계를 가지고 있다. 때문에 과거 매출 자료에만 의존하지 않고 제 품 속성이나 시기별 마케팅 활동 정보를 고려 하는 모형이 제안되었으나, 여전히 제품 출시 초기에 매출 예측을 하는 데는 적합하지 않은 것으로 평가 받고 있다(Golder and Telli 1997). 셋째, 확산 과정을 이해하기 위해 확산을 결 정하는 시기별 소비자의 특징을 설명하는 연 구(Rogers 1969, Bass 1969)가 이루어져왔다. Rogers(1969)는 확산 과정상에서 신제품을 수 용하는 시간에 따라 소비자를 혁신자, 초기구 매자, 초기다수자, 후기다수자, 최종구매자 등 으로 구분하였고, $\operatorname{Bass}(1969)$ 는 신제품 확산 예측 모형을 개발하는 과정에서 소비자를 신제 품 수용 시점에 의해 혁신자(innovator)와 모 방자(imitator)로 구분하였다.

반면에 제품 생명 주기상의 전환시점(turning point)에 대한 기존 연구는 매우 부족한 실정이 다(Golder \& Tellis 1997). Golder \& Tellis (1997)은 제품 생명 주기상의 이륙 시점 예측 에 관한 최초의 연구로 제품 가격, 제품 도입 년도, 시장 침투율(제품을 구매한 가구의 비 율)을 설명변수로 이용하여 이륙 시점을 예측 하는 모형을 제안하고, 31 개 내구재 제품 매출 자료를 이용하여 실증 분석하였다. Muller \& Yogev(2005)은 매출 이륙 시점보다는 변곡 시 점(inflection point)에 더 가까운 개념인 주고객 집단의 변화 시점(Change-Of-Dominance timing) 이라는 개념을 제시하고 이 시점을 실증 분석 을 통해 언제 발생하는 지를 탐색적 접근을 통 해 분석하였다. 즉, 제품 생명 주기에 따라 시 장은 초기시장(early market)과 주 시장(main market)이라는 2개의 복수 시장(dual-market) 으로 구성된다고 보았다. 시간이 경과함에 따라 이 시장을 구성하는 주 시장의 고객(main market adapters) 수가 초기 시장의 고객(early market adapters) 수 보다 커지는 시점을 주 고객 집 단의 변화 시점이라고 정의하고, 실증 분석을 통해 26 개 전자 제품군에서 주 고객 집단의 변 화 시점을 복수 시장 구조 모형(dual-market structure model)을 이용하여 추정하였다. 이 연구는 주 고객 집단의 변화 시점을 여러 산업 의 매출 자료를 이용해 측정한 뒤, 주 시장의 고객이 시장의 주류로 바뀌는 시점이 일반적으 로 전체 고객 중 $16 \%$ 가 제품을 구매했을 때라 는 탐색적 분석 결과를 보여주고 있다.

이와 같이 기존 연구는 모두 시장 전체 수준 의 제품 수명 주기상에 나타나는 전환 시점을 다루어 왔다. 반면에, 특정 제품을 판매하는 기 업의 입장에서 보다 유용한 정보인 제품 수준

\section{6 한국마케팅저널 제10권 제2호 2008년 7월}


의 전환 시점 예측에 대한 연구는 전무한 상태 이다. 기본적으로 시장 전체 수준의 수명 주기 와 제품 수준의 수명 주기 모두 시간에 따른 매출로 형성되는 것이나, 제품 수준의 매출 이 륙 시점 예측에 대한 연구는 시장 전체 수준의 수명 주기상 이륙 시점 예측 연구와 다른 접근 법이 필요하다. 왜냐하면 제품 수준의 생명 주 기와 시장 전체 수준의 생명 주기가 적어도 다 음 3 가지 관점에서 다르기 때문이다. 첫째, 시 장 수준의 생명 주기는 시장 내 복수 제품의 매출로 구성되는 반면에 제품 수준의 생명 주 기는 상대적으로 적은 양인 단일 제품의 매출 자료로 구성되기에 전체 수준의 매출에 비해 시기에 따른 매출 변동이 상대적으로 크다. 때 문에 매출 이륙 시점을 결정하는 것이 어려우 며, 매출 이륙 시점을 측정하는 방법을 달리 할 필요가 있다. 둘째, 제품 수준의 생명 주기상에 존재하는 매출 이륙 시점에 영향을 미치는 변 수 역시 기업 관점에서 고려할 변수가 달라진 다. 예를 들어, 시장 수준에서는 시장 전체 가 격이 중요하나 개별 제품 수준에서는 시장 평 균 가격 대비 제품 가격 비율 등 추가적으로 고려할 변수들이 존재한다. 셋째, 시장이 성숙 기에 다가갈수록 기업의 입장에서는 시장 수준 의 생명 주기보다는 개별 제품 수준의 생명 주 기나 매출 이륙 시점 예측이 중요해 진다. 시장 초기에는 개별 기업도 시장 전체 규모의 성장 이 자사 개별 제품의 성장에 직접적인 영향을 미치나, 시장 전체가 성숙기에 도달할 수록, 시 장 전체 성장 보다는 개별 기업의 성장에 관심 을 기울이기 때문이다.

\section{2 매출 이륙 시점 측정 방법}

제품 매출 곡선상의 이륙 시점을 실증 분석하 기 위해서는 우선 이륙 시점을 어떻게 측정할 것인지를 결정해야 한다. 기존 연구를 보면 매 출 이륙 시점을 측정하는 방법은 크게 3 가지로 구분할 수 있다. 첫 번째 방법은 아래 (식1)과 같이 제품 $\mathrm{j}$ 의 매 시점 $\mathrm{t}$ 별 판매량 $S_{j}(t)$ 을 초 기 판매량 $S_{j}(1)$ 대비 비율 $R_{j}(t)$ 로 계산한 뒤 시기별로 이 비율을 표시하여, 비율 곡선상에서 $R_{j}(t)$ 이 급격하게 증가하는 시점을 이륙 시점 으로 결정하는 방법이다(Golder and Telli 1997). 편의상 이 방법을 한계 규칙(Threshold Rule) 모형이라고 칭하고자 한다.

$$
\begin{aligned}
R_{j}(t) & =\frac{S_{j}(t)}{S_{j}(1)} \\
S_{j}(t) & : \text { t기의 제품 } \mathrm{j} \text { 판매량 } \\
S_{j}(1) & \text { : 판매 발생 첫 번째 시점 }
\end{aligned}
$$

Golder and Tellis(1997)의 연구에서 컬러 텔 레비전, 자동응답기 등과 같은 소비재 제품군들 의 초기 판매량 대비 성장률 곡선을 그리면 31 개의 제품군 중 28 개의 제품군에서 시각적으로 구별할 수 있는 급격한 판매량의 변화가 보이 는 것으로 나타났다(Golder and Tellis 1997). 이 방법은 초기 판매량 대비 판매량 성장률의 곡선을 그렸을 때 명확하게 이륙시점을 구별할 수 있는 시점이 존재할 경우에는 용이하게 쓸 수 있다. 하지만 매출 곡선이 매우 완만해서 곡 선상의 뚜렷한 이륙시점이 잘 나타나지 않거나 반대로 매출이 급격하게 증가 감소를 반복하는 경우에는 측정한 매출 이륙 시점이 측정하는 
사람에 따라 작의적으로 결정될 수 있는 문제 점을 가지고 있다. Golder \& Telli (1997)의 연구 에서는 첫 번째인 한계 규칙(Threshold Rule) 모형을 이용하여 매출 이륙 시점을 측정하였다.

두 번째 방법으로는 매출 자료를 이용해 로지 스틱 곡선을 추정하고, 추정된 로지스틱 곡선상 에서 기울기 변화가 가장 큰 시점, 즉, 매출 증 가율이 가장 높은 시점을 이륙 시점으로 측정 하는 것이다(로지스틱 곡선 규칙(Logistic Curve Rule). 즉, 먼저 매출 자료에 근거해 누적 확률 분포 함수를 로지스틱 곡선으로 추정한 뒤, 이 함수를 2 차 미분하여 기울기 변화가 최대값이 되는 시점을 이륙시점으로 측정하는 것이다. 이 방법은 첫 번째 방법인 한계규칙 모형을 적용 하기 어려운 상황, 즉 매출 곡선이 매우 완만한 경우에 적용하기 적합한 방법이다. 반면에 매출 이륙 시점이 로지스틱 함수 가정하에 만들어진 누적 곡선에 의해 결정되므로 매출 함수가 변 곡시점을 중심으로 비대칭한 패턴을 갖는 경우 이륙 시점을 적절히 측정하기 못할 가능성이 있다. 또한 도입기에서 성장기로 넘어서는 시점 에 매출 변동이 심할 경우에는 증가율이 낮은 시점을 이륙 시점으로 측정하게 되는 오류를 범할 수도 있다.

세 번째 방법은 로지스틱 곡선을 이용한 두 번째 방법을 보완한 방법으로 매출 이륙 시점 을최대 성장률 규칙(Maximum Growth Rule) 에 따라 측정하는 방법이다. 즉, 두 번째 방법 에서 제시된 로지스틱 곡선 규칙에 따라 선정 한 이륙시점 $(\mathrm{t}$ 기)을 기준으로 전후 3 기 내에서 판매량 증가율 중 최대값(식 2)을 보이는 시점 을 이륙 시점으로 산정하는 방법이다.

\section{III. 연구 모형}

본 연구는 복수의 시장에서 제품을 판매하고 있는 기업이 매출 이륙 시점을 예측하는 데 필 요한 모형을 수립하고, 이 모형을 이용해 매출 이륙 시점 예측에 도움이 되는 설명 변수를 찾 아내고자 한다. 특히, 해외 여러 시장에 제품을 판매하고 있는 기업의 입장에서 대상 제품의 타 시장 확산 정보가 대상 제품의 표적 시장 매출 이륙 시점에 미치는 영향과 반대로 기존 에 판매된 다른 제품들의 표적 시장에서의 확 산 정보가 대상 제품의 표적 시장에서의 매출 이륙 시점에 미치는 상대적인 영향을 살펴 보 고자 한다.

\section{1 매출 이륙 시점(Take-off timing) 예측 모형}

기존의 확산 모형 연구를 매출 이륙 시점 예 측에 적용할 경우, 예측에 필요한 정보의 설명 력 부족이 가장 큰 문제이다. 사전 매출 자료를 이용하여 향후 매출 이륙 시점을 예측할 경우, 매출 이륙 시점이 매출 초기에 발생하기에 이 용할 수 있는 사전 매출 자료가 매우 적기 때 문이다. 본 연구에서는 이를 해결하기 위해 복 수의 시장에서 제품을 판매하고 있는 기업들이 사전 매출 자료 이외에 일반적으로 쉽게 획득 할 수 있는 정보를 매출 이륙 시점 예측의 설 명 변수로 도입하여 그 효과를 보고자 한다. 때 문에 본 연구 모형에서는 크게 5 가지 유형의 정보를 설명 변수로 고려하였고 이 변수들이 예측에 기여하는 바를 분석하였다: (1) 표적 
제품이 다른 여러 시장에서 얼마나 빨리 확산 되었는 지를 의미하는 대상 제품의 시장 성과 정보, (2) 표적 시장이 일반적으로 기존 신제품 들을 얼마나 빨리 받아들였는지, 즉 표적 시장 의 제품 확산 성향에 관한 정보, (3) 대상 제품 의 속성(product attribute) 정보, (4) 대상 제 품의 가격(price) 정보, 그리고 (5) 대상 제품 의 매출(sales) 정보

위 5 가지 유형의 설명 변수를 매출 이륙 시점 예측을 위해 고려한 이유와 측정 방법을 설명 하면 다음과 같다. 우선, 본 연구에서 분석하고 자 하는 가장 주요한 과제는 일반 기업들과 달 리 복수의 시장에 진출한 기업이 일반적으로 보유하게 되는 추가적인 시장 정보를 이용하여 매출 이륙 시점 예측 성과를 향상 시킬 수 있 는 지를 알아 보는 것이다. 좀 더 구체적으로 보면, 가장 주요한 분석은 대상 제품이 과거 다 른 해외 시장에서 어느 정도의 속도로 확산 되 었는 지와, 표적 시장에서 과거 다른 유사 제품 들이 어느 정도의 속도로 확산 되었는 지를 아 는 것이 대상 제품의 표적 시장에서의 매출 이 륙 시점을 예측하는 데 얼마나 도움이 될 수 있는 가를 평가하는 것이다.

이를 위해서 첫째, 표적 시장에 이미 진입한 타 제품들의 확산 정도가 대상 제품의 매출 이 륙 시점 예측에 미치는 영향을 알아보고자 한 다. 기존 제품들이 시장에서 어느 정도 속도로 어떻게 확산 되었는 지를 안다면 자사 신제품 이 시장에 출시될 경우 언제 이륙(take-off)을 하게 될 지를 예측하는 데 도움이 될 수 있을 것이라고 판단된다. 설명 변수로 특정 시장에서 의 제품 확산 정도가 매출 이륙 시점에 미치는 영 향을 분석하기 위해 조작적 변수로 Bass 모형
에서 제시하는 혁신 계수(Innovation coefficient) 와 모방 계수(Imitation coefficient)를 이용하고 자 한다. 즉, Bass 모형을 표적 시장에서의 기 존 복수의 제품 매출 자료에 적용하여 작성한 혁신 성향 계수 평균치와 모방 성향 계수 평균 치를 표적 시장의 제품 확산 성향 변수로 이용 하고자 한다. 표적 시장 역시 시장 자체로서 제 품을 받아들이는 일정한 특징을 지니고 있다면, 특정 시장에서 장기적으로 여러 제품을 판매하 는 기업의 입장에서는 다른 제품에 대해서 표 적 시장이 유사한 매출 반응을 보이는 지를 아 는 것이 기업의 입장에서 유용한 정보가 될 것 이라고 판단했기 때문이다. 또한, 동일 시장이 여러 제품에 대해 매출상 유사한 반응을 보인 다면, 대상 제품의 표적 시장에서의 매출 이륙 시점을 예측하는 데 도움을 유용할 것이다.

둘째, 타 시장에서 대상 제품이 어떻게 확산 되었는 지를 의미하는 타 시장에서 대상 제품 의 혁신성향 계수 평균치와 모방 성향 계수 평 균치가 매출 이륙 시점에 미치는 영향을 분석 해 보고자 한다. 대상 제품의 타 시장 성과 정 보를 설명 변수로 선정한 이유는 복수의 시장 이 동일 제품에 대해 유사한 매출 반응을 보이 는 지를 아는 것이 표적 시장에서의 동일 제품 매출을 설명하는 데 유용한 정보가 될 것이라 고 판단했기 때문이다. 만일 복수의 시장에서 동일 제품에 대해 유사한 반응을 보인다면, 표 적 시장에서의 매출 이륙 시점을 예측하는 데 도움을 받을 수 있을 뿐만 아니라 여러 시장의 제품 생명 주기 관리를 종합적, 유기적으로 계 획할 수 있다는 주요한 시사점을 얻을 수 있을 것이다.

셋째, 해당 제품의 속성(product attribute) 
정보는 제품 매출을 결정하는 가장 주요하고 기본적인 정보이며 매출 이륙 시점은 기본적으 로 매출에 의해 결정되는 것이므로 제품 특성 을 설명 변수로 고려하였다. 대상 제품인 TV 구매시 소비자들이 일반적으로 가장 주요하게 고려하는 TV의 핵심 패널 유형(PDP 또는 $\mathrm{LCD}$ 여부)과 디스플레이의 크기(인치 기준)을 대상 제품의 매출 이륙 시점 설명 변수로 고려 하였다. 시장 수준의 이륙 시점 예측에서는 제 품 속성이 이륙 시점 예측에 큰 도움을 주지 못하는 것으로 분석되었다(Golder and Telli 1997). 하지만 본 연구는 제품 수준의 매출 이 륙 시점을 예측하고자 하기에 제품 속성의 역 할이 보다 중요할 것이라고 판단하여 효과를 평가하고자 한다.

넷째, 매출 이륙 시점을 예측하는 데 있어 판 매 가격을 고려하고자 한다. 보통 시장에 출시 되는 신제품은 고가로 가격을 형성하다가 점차 가격을 낮추는 경우가 많은 데 가격 감소에 따 라 시장 수요가 민감하게 반응하기에 가격은 매출 이륙 시점 예측에 주요한 역할을 할 것으 로 예상된다. 가격 변수로는 대상 제품의 시기 별 가격과 대상 제품 가격의 시장 경쟁력을 고 려하기 위해 시장 평균 가격(시장 내 타 제품 의 평균 가격) 대비 대상 제품의 가격 비율을 선정하였다. 특히 가격은 기업의 입장에서 사전 에 결정할 수 있는 변수로 향후 매출 이륙 시 점에 영향을 줄 수 있는 수단이므로 기업의 입 장에서는 제품 수명 주기 관리를 위해 관심을 갖는 중요한 변수이다.

마지막으로, 대부분의 확산 모형이 주요 설명 변수로 고려하는 예측 시점 전기까지의 누적 매출 자료를 설명변수로 고려하였다. 기본적으
로 매출 이륙 시점은 매출에 의해 결정되는 것 이며, 일반적으로 모든 확산 모형은 전기까지의 누적 매출 자료를 주요 설명변수로 이용한다.

본 연구는 이륙 시점 예측 모형을 해저드 함 수 중 대표적인 모형인 $\mathrm{Cox}$ 비례 위험 모형 방식을 채택하여 다음과 같이 구성하였다. 즉, 특정 시장 $\mathrm{g}$ 에서 대상 제품 $\mathrm{j}$ 의 매출 이륙이 시점 t에 발생할 확률 $h_{j g}(t)$ 은 기저 위험 함수 (hazard function) $h_{o j g}(t)$ 와 아래 설명 변수 $\mathrm{X}$ 를 이용하여 다음 (식 2)와 같이 표현할 수 있다.

$$
\begin{aligned}
h_{j g}(t) & =h_{o j g}(t) \exp \left[\beta_{1} X_{1 j g}+\beta_{2} X_{2 j g}+\beta_{3} X_{3 j g}\right. \\
& +\beta_{4} X_{4 j g}+\beta_{5} X_{5 j g t}+\beta_{6} X_{6 j g t}+\beta_{7} X_{7 j g} \\
& \left.+\beta_{8} X_{8 j g}\right]
\end{aligned}
$$

$\mathrm{j}=\mathrm{j}$ 번째 제품

$\mathrm{t}=$ 시기

$\mathrm{X}_{1 \mathrm{jg}}$ : 표적 시장의 타제품 평균 혁신 성향 계수

$\mathrm{X}_{2 \mathrm{jg}}$ : 표적 시장의 타제품 평균 모방 성향 계수

$\mathrm{X}_{3 \mathrm{gg}}$ : 대상 제품의 타 시장 평균 혁신 성향 계수

$\mathrm{X}_{4 \mathrm{jg}}$ : 대상 제품의 타 시장 평균 모방 성향 계수

$\mathrm{X}_{5 \mathrm{jgt}}$ : 제품의 평균가격

$\mathrm{X}_{6 \mathrm{jgt}}$ : 시장가격 대비 제품 평균가격 비율

$\mathrm{X}_{7 \mathrm{jg}}$ : 디스플레이 종류 (PDP 또는 LCD TV 여부)

$\mathrm{X}_{8 \mathrm{jg} g}$ : 디스플레이 액정 크기(인치)

설명 변수 중 표적 시장의타제품 평균 혁신 성향 계수와 평균 모방 성향 계수는 표적 시장 에서 해당 제품 출시 전 시장에서 출시된 제품 들의 매출 자료에 Bass모형(Bass 1969)을 적용 하여 각각 추정한 혁신 성향 계수(Innovation coefficient)들의 평균치와 모방 성향 계수 (Immitation coefficient)들의 평균치를 이용하 
였다. 또한, 대상 제품의 타 시장 평균 혁신 성 향 계수와 평균 모방 성향 계수는 표적 시장을 제외한 다른모든 시장에서 해당 제품의 매출 자료에 Bass 모형을 적용하여 추정한 혁신 성 향 계수의 평균치와 모방 성향 계수들의 평균 치를 이용하였다. 혁신 성향 계수와 모방 성향 계수를 추정하는 데 여러 Bass 모형을 적용할 수 있으나 표준 모형의 경우 다른 비선형 모형 추정 방식들에 비해 추정에 필요한 시간이 상 대적으로 매우 적으므로, 90 개 제품의 각 시장 에서의 혁신 계수와 모방 계수를 추정해야 하 는 본 실증 분석에서는 가장 현실적인 대안이 라고 판단하였다.

비례 위험 모형을 추정하기 위해 위 (식 2)를 이용해 아래 (식 3)과 같이 부분 우도 함수 (partial likelihood function)를 도출하였다.

$$
L(\beta)=\prod_{j=1}^{D} \frac{\exp \left(\beta^{t_{j}} s_{j}\right)}{\prod_{k=1}^{d_{j}}\left[\sum_{p \in R_{j}} \exp \left(\beta^{t_{j}} X_{p}\right)-\frac{k-1}{d_{j}} \sum_{p \in D_{j}} \exp \left(\beta^{t_{j}} X_{p}\right)\right]}
$$

$\mathrm{D}: t_{1}<t_{2}<\cdots<t_{D}$ D개 제품별 순서화된 매출 이 륙 발생시간

$\mathrm{d}_{\mathrm{j}}: \mathrm{t}_{\mathrm{j}}$ 시점에 발생한 매출 이륙 수

$\mathrm{D}_{\mathrm{j}}: \mathrm{t}_{\mathrm{j}}$ 시점에 매출 이륙이 발생한 모든 제품의 집합

$\mathrm{S}_{\mathrm{j}}: \mathrm{t}_{\mathrm{j}}$ 시점에 매출 이륙이 발생한 모든 제품의 설 명변수 벡터(vector) $\mathrm{X}_{\mathrm{i}}$ 의 합

$$
\text { 즉, } s_{j}=\sum_{p \in D_{j}} X_{p}
$$

$\mathrm{R}_{\mathrm{j}}$ : $\mathrm{t}_{\mathrm{j}}$ 시점 직전에매출 이륙 가능성이 있는 모든 제품의 집합

이 부분 우도 함수(partial likelihood function)
에 최대 우도 추정 방법(Efron 1977)을 적용하 여 모형을 추정 하였다.

\section{2 매출 이륙 시점 측정}

Golder \& Telli (1997)의 연구에서는 앞서 언 급한 3 가지 매출 이륙 시점 측정 방법 중 첫 번째인 한계 규칙(Threshold Rule) 모형을 이 용하였다. 이 연구에서는 사용한 자료가 시장 수 준의 혁신 소비재(Really New Consumer Goods) 매출 자료로 자료 특성 상 매출 이륙 시점이 시각적으로 쉽게 판단이 가능한 경우가 많았기 에 첫 번째 한계 규칙 모형을 적용하기가 용이 하였다. 반면에, 본 연구는 시장 전체 차원이 아닌 특정 제품 수준의 매출 자료를 연구 대상 으로 하고 있기에 매출 곡선상의 매출 이륙 시 점을 시각적으로 뚜렷하게 확인하기 어려운 경 우가 많다. 또한, 본 연구에서 다루고 있는 매 출 자료는 충분한 기간에 걸쳐 수집된 다양한 제품 매출 자료이기에 보다 객관적인 방법인 2, 3 번째 측정 방법을 쓰는 것이 바람직하다. 또 한, 개별 제품 수준의 매출 자료의 경우 매출이 단기간에도 비교적 크게 변동하기에 3 번째 측 정 방법인 최대 성장률 모형을 적용하였다.

이 방법은 두 가지 과정을 거쳐 진행되는 데, 먼저 기존 매출 자료를 이용해 누적 확률 함수 를 추정해야 한다. 이때 적용할 누적 확률 함수 로 어떤 함수를 쓸 것인지는 분석에 쓰이는 자 료와의 적합성을 기준으로 선별하게 된다. 예를 들어, 매출의 매출 형태가 매출 정점을 중심으 로 대칭형 (symmetric data)인 경우에는 보통 로지스틱 곡선 모형을 사용할 수 있으며, 매출 이 비대칭적(asymmetric data)인 경우에는 대 
표적으로 곰페르츠 곡선 모형을 쓸 수 있다 (Meade and Islam 1998). 본 연구에서 다루고 있는 매출 자료는 전체적으로 대칭형에 가까운 경우가 많아, 매출 곡선으로 로지스틱 곡선을 가정하였다. 이 경우 특정 시점 $\mathrm{t}$ 기까지의 누적 구매확률인 $F(t)$ 의 $t$ 기에 대한 미분 $f(t)$ 가 (식 4) 와 같은 형태를 갖는다.

$$
\frac{\partial F}{\partial t}=f(t)=q F(t)(1-F(t))
$$

(식 4)으로부터 다음과 같은 위험함수(hazard function)를 도출하게 된다.

$$
\frac{f(t)}{(1-F(t))}=q F(t)
$$

즉 $\mathrm{t}$ 기에 구매할 확률은 이미 구매한 누적 확 률에 비례한다는 것으로 미분방정식을 통해 푼 (식 5)은 로지스틱 곡선의 형태가 된다.

$$
F(t)=\frac{1}{1+\alpha \exp (-\beta t)}+\varepsilon_{t} \quad(\alpha, \beta>0)
$$

(식 6)의 로지스틱 곡선을 2차 미분하여 최대 값이 나오는 시점 $(\mathrm{t})$ 을 측정 한다. 마지막으로, 찾아낸 $\mathrm{t}$ 기를 기준으로 전후 3 기 정도의 판매 량 변화율을 (식 7)와 같이 계산한 뒤, 이 중 최대값을 보이는 시점을 이륙 시점으로 측정하 였다. ${ }^{2)}$

$$
\operatorname{Max}\left[\frac{\mathrm{S}(\mathrm{t}-3)}{\mathrm{S}(\mathrm{t}-4)}, \frac{\mathrm{S}(\mathrm{t}-2)}{\mathrm{S}(\mathrm{t}-3)}, \frac{\mathrm{S}(\mathrm{t}-1)}{\mathrm{S}(\mathrm{t}-2)}, \frac{\mathrm{S}(\mathrm{t})}{\mathrm{S}(\mathrm{t}-1)}, \frac{\mathrm{S}(\mathrm{t}+1)}{\mathrm{S}(\mathrm{t})}, \frac{\mathrm{S}(\mathrm{t}+2)}{\mathrm{S}(\mathrm{t}+1)}, \frac{\mathrm{S}(\mathrm{t}+3)}{\mathrm{S}(\mathrm{t}+2)}\right]
$$

$\mathrm{t}$ : 로지스틱 곡선 규칙으로 규정한 이륙 시점이 발생한 시기

$\mathrm{S}(\mathrm{t})$ : $\mathrm{t}$ 기의 판매량

\section{IV. 실증 분석}

본 연구는 실증 분석을 위해 해외 여러 시장 에 TV를 생산, 판매하고 있는 전자 업체(편의 상 앞으로는 $\mathrm{K}$ 전자로 표기하고자 한다.)가 2003년 1월부터 2006년 5월까지 2년 5개월간 해외 10 개국에서 판매한 $\mathrm{PDP} \mathrm{TV}, \mathrm{LCD} \mathrm{TV}$ 월별 매출 자료를 이용하였다. 이중에서도 관찰 기간 내에 매출이 발생하기 시작해서 관찰 기 간 내에 단종된 제품과 관련 대상 국가를 선정 하였고 그 결과 90 개 제품의 매출 자료를 선정 하였다. 즉, 실증 분석에서 이용한 제품은 $\mathrm{LCD}$ $\mathrm{TV}$ 47개, PDP TV 43개로 총 90개이며, 이들 제품이〈표 1〉과 같이 10 개국 시장 중 어느 한 시장에서 발생한 매출 자료를 이용하여 실증 분석을 하였다.

실증 분석을 위한 첫 번째 단계로 각 시장에 서 제품별 매출 이륙 시점을 측정하였다. 앞서 설명한 3 번째 측정 방법인 최대 성장률 모형을 자료에 적용하여 각 제품의 매출 이륙 시점을 각 시장 별로 측정하였는데 매출 이륙 시점의 분포를 〈그림 2〉에서 살펴 볼 수 있다.

〈그림 2)를 보면, 제품이 출시 후 매출 이륙 까지 도달하는 시점은 평균 5.66 개월이나 표준

2) 두 번째 방법에서 제시하는 이륙시점을 무시하고, 단순히 각 기별 성장률을 비교한 뒤 오직 최대 성장률을 나타낸 시점 을 이륙시점으로 측정할 수 도 있다. 하지만 제품 수준의 매출 곡선과 같이 단기 변동이 매우 큰 경우에는, 매출 이륙 시점이 지나치게 이른 시점이나 늦은 시점으로 결정될 가능성이 높아진다. 
〈표 1〉제품의 시장 별 분류

\begin{tabular}{|c|cc|c|}
\hline 지 역 & LCD TV 제품 수 & PDP TV 제품 수 & 총 합 계 \\
\hline 미국 & 6 & 6 & 12 \\
영국 & 6 & 1 & 7 \\
프랑스 & 8 & 6 & 14 \\
독일 & 7 & 5 & 12 \\
홍콩 & 5 & 6 & 11 \\
중국(홍콩제외) & 4 & 4 & 8 \\
인도 & 2 & 3 & 5 \\
브라질 & 3 & 4 & 7 \\
일본 & 6 & 4 & 10 \\
러시아 & 0 & 4 & 4 \\
\hline 총합계 & 47 & 43 & 90 \\
\hline
\end{tabular}

〈그림 2〉매출 이륙 시점 분포

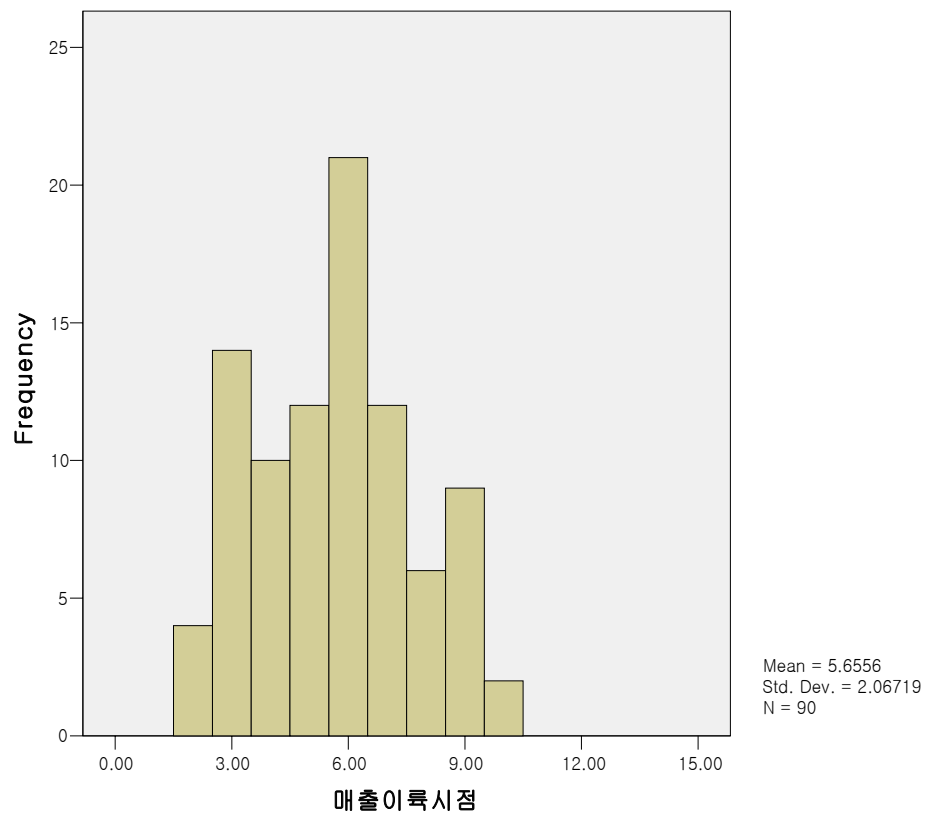

편차가 2.07로 시장별, 제품별로 매출 이륙 시 9개월 사이에 대부분 발생하는 것을 알 수 있 점이 매우 다양함을 알 수 있다. 각 시장에서의 었으며, 특히 6개월째에 가장 많이 발생하며, 개별 제품 매출 이륙 시점은 대부분 3 개월부터 그 다음으로는 3 개월째에 자주 발생함을 알 수 
있었다.

실증 분석을 위한 두 번째 과제로 예측에 이 용할 설명 변수를 측정하였다. 첫 번째설명 변 수인 대상 제품의 타 시장 평균 혁신 계수는 동일 제품이 여러 시장에서 판매될 경우 해당 제품의 시장 별 혁신 계수들의 평균치를 이용 하였다. 모든 제품별 평균 제품의 혁신계수와 평균 모방계수 추정치를 예시하기 위해 미국 시장에서의 제품 제품별 혁신 계수와 모방 계 수를〈표 2〉에 정리하였다.

두 번째 설명 변수인 타 제품의 표적 시장에 서의 평균 혁신 계수와 평균 모방 계수 지수는 표적 시장에서 이미 판매된 타 제품들의 혁신 계수와 모방 계수의 평균값을 의미한다. 실증 분석을 통해 측정한 평균 혁신 계수와 평균 모 방 계수 지수는 〈그림 3〉과 〈그림 4〉에 정리하 였다.

세 번째 설명 변수로 제품 특성 정보를 고려
하였다. TV 디스플레이의 경우 소비자가 고려 하는 주요 제품 특성은 화질의 차이로 인식이 되고 있는 TV 디스플레이의 패널 유형(PDP/ $\mathrm{LCD})$ 과, 영상의 크기를 나타내는 디스플레이 크기(인치) 2 가지 이다. 분석에 이용된 제품의 특성은 〈표 3〉과 같다.

네 번째 설명 변수로 본 연구는 제품 가격 관 련 두 가지 변수를 고려하였다. 대표적인 가격 변수로 해당 제품의 매월 평균 가격과 시간에 따른 가격 인하가 매출 이륙 시점에 미치는 영 향을 측정하고자 시장 내 타 제품의 가격 평균 대비 해당 제품 가격 비율 2가지를 가격 관련 변수로 고려하였다. 가격 효과에 대한 분석 결 과는 향후 매출 이륙 시점을 앞당기기 위해 미 래 가격 정책을 개발하는 데 또한 도움이 될 것으로 분석할 가치가 있다고 판단하였다. 마지 막으로, 확산 모형에서 가장 주요한 제품의 시 기 별 매출액을 다섯 번째 설명 변수로 선정하

〈표 2〉대상 제품의 타 시장 평균혁신계수와 평균모방계수

\begin{tabular}{|c|c|c|c|c|c|}
\hline 지역 & 모델명 & Type & Inch & 평균혁신계수 & 평균모방계수 \\
\hline 미국 & 1 & LCD & 17 & 0.02922513 & 0.232539855 \\
\hline 미국 & 2 & LCD & 15 & 0.025795986 & 0.220996836 \\
\hline 미국 & 3 & LCD & 17 & 0.011175834 & 0.293606434 \\
\hline 미국 & 4 & PDP & 50 & 0.033836465 & 0.216152565 \\
\hline 미국 & 5 & LCD & 22 & 0.023979542 & 0.098270942 \\
\hline 미국 & 6 & LCD & 32 & 0.037031285 & 0.174656869 \\
\hline 미국 & 7 & LCD & 17 & 0.012713519 & 0.570835219 \\
\hline 미국 & 8 & PDP & 42 & 0.033665027 & 0.415626116 \\
\hline 미국 & 9 & PDP & 42 & 0.034681851 & 0.426791851 \\
\hline 미국 & 10 & PDP & 42 & 0.019876136 & 0.309984693 \\
\hline 미국 & 11 & PDP & 50 & 0.033478823 & 0.199178143 \\
\hline 미국 & 12 & PDP & 42 & 0.031745186 & 0.404328106 \\
\hline
\end{tabular}

14 한국마케팅저널 제10권 제2호 2008년 7월 
〈그림 3〉 표적 시장의 평균 혁신 계수

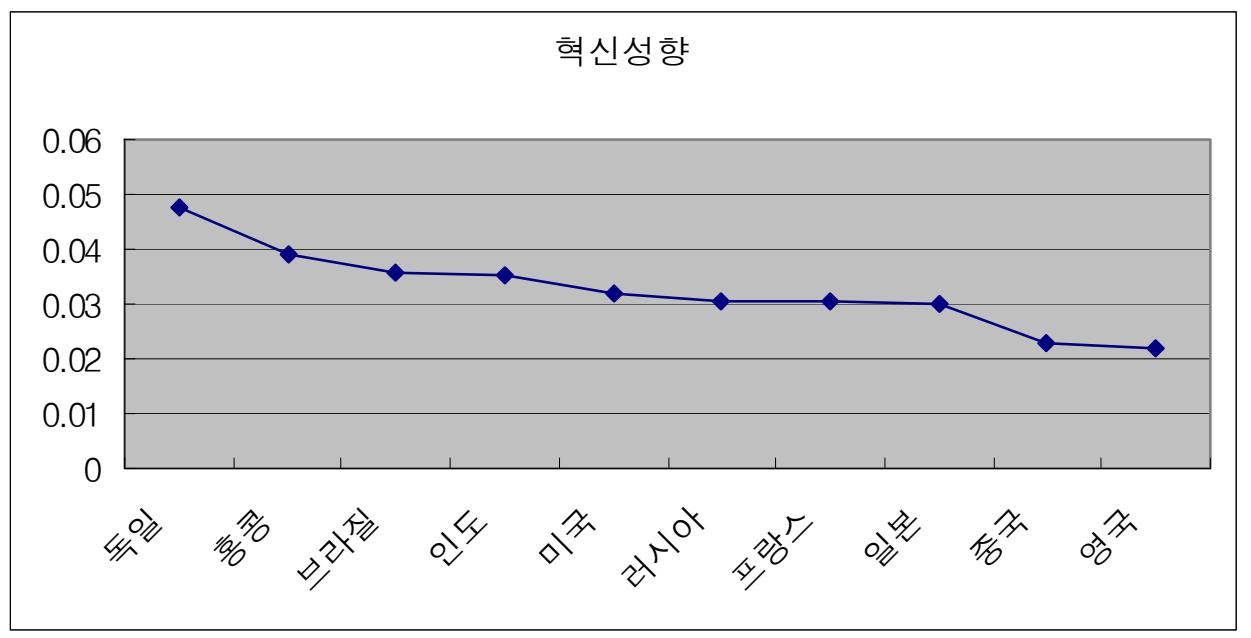

〈그림 4〉 표적 시장의 평균 모방 계수

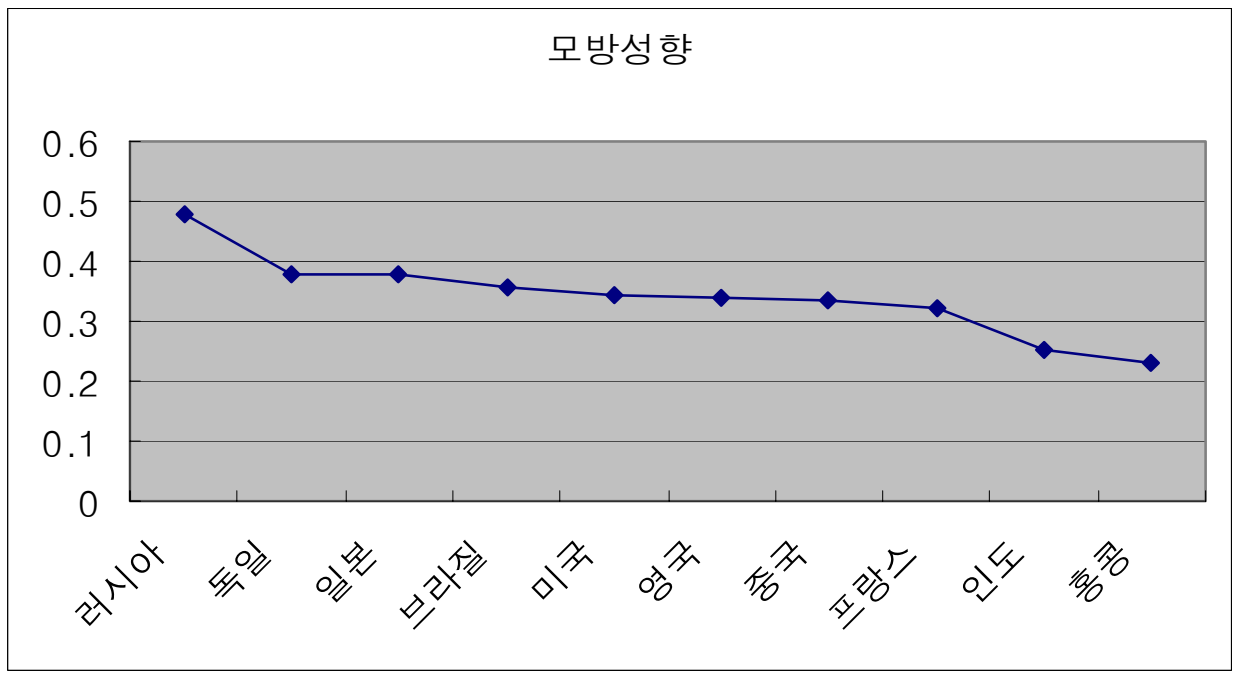

였다.

매출 이륙 시점 모형은 앞서 설명한 이륙 시 점에 영향을 미치는 변수들의 상대적 중요도 비교를 위해 총 4 가지를 실증 자료에 적용하여 분석하였다. 첫 번째 모형은 앞서 설명한 모든 설명 변수를 고려한 대표 모형 (Model I)이며,
두 번째 모형은 설명 변수 중 표적 시장의 타 제품 확산 성향 효과를 고려하지 않은 모형 (Model II), 세 번째 모형은 설명 변수 중 대상 제품의 타 시장 확산 성향 정보를 고려하지 않 은 모형(Model III), 그리고 마지막 모형은 가 격 변수를 고려하지 않은 모형(Model IV)이다. 
〈표 3〉 제품의 인치별 분류

\begin{tabular}{|c|c|c|c|}
\hline 인치 & LCD TV & PDP TV & 총합계 \\
\hline 15 & 10 & & 10 \\
\hline 17 & 9 & & 9 \\
\hline 20 & 5 & & 5 \\
\hline 22 & 4 & & 4 \\
\hline 26 & 5 & & 5 \\
\hline 32 & 12 & & 12 \\
\hline 37 & & 3 & 3 \\
\hline 40 & 2 & & 2 \\
\hline 42 & & 32 & 32 \\
\hline 50 & & 8 & 8 \\
\hline 총합계 & 47 & 43 & 90 \\
\hline
\end{tabular}

제품 속성과 누적 매출액은 예측 모형이 이용 하는 기본 정보이며 본 연구의 효과 평가 대상 이 아니므로 이 변수들을 고려하지 않은 모형 은 모형 비교 결과를 생략하였다. 이 네 가지 모형을 각각 추정 매출 이륙 시점 예측 모형의 추정은 통계 패키지 STATA 10 을 이용하였다. 하였으며, 그 결과를 정리하면 다음 〈표 4〉와 같다.

우선 다섯 가지 설명 변수를 모두 이용한 모 형 I의 모수 추정 결과(표 4 두 번째 열)를 보 면, 유의 수준 $5 \%$ 하에서 유의한 설명 변수는 시장 확산 변수 중 표적 시장의 평균 혁신 계 수, 대상 제품의 타 시장 평균 혁신 계수이며, 제품 속성 변수 중 디스플레이 크기, 그리고 제 품의 가격 변수 두 가지와 전기까지의 누적 판 매량이다. 이 결과에 따르면, 시장 확산 정보 중 혁신 계수와 달리 모방 계수는 표적 시장의 모방 계수건 대상 제품의 타 시장 모방 계수건 모두 매출 이륙 시점 예측에 적합하지 않아 오
직 혁신계수만을 설명 변수로 고려하는 것이 바람직하다고 판단된다. 특히, 혁신 계수가모방 계수보다 매출 이륙 시점 예측에 보다 유용한 정보라는 점은 매출 이륙 시점이 시장의 혁신 성향에 의해 크게 좌우된다는 기존의 견해를 확인시켜주는 결과이다. 제품 속성 변수 역시 매출 이륙 시점 예측에 필요한 정보인데, $\mathrm{TV}$ 의 크기는 매출 이륙 시점 예측에 중요하나, 제 품이 $\mathrm{LCD}$ 인지 $\mathrm{PDP}$ 인지 여부는 매출 이륙 예 측에 도움이 되지 않음을 알 수 있었으며, 디스 플레이 크기가 커질수록 매출 이륙 시점이 빨 라짐을 알 수 있었다. 두 가지 가격 변수는 모 두 매출 이륙 시점 예측에 보다 유용한 정보임 을 알 수 있었다. 특히, 시장 평균 가격 대비 대상 제품 가격 비율은 기존 시장 전체 수준의 PLC 연구에서는 다루어 지지 않은 변수이나 제품 수준의 매출 이륙 시점 연구에서 이용할 가치가 있는 중요한 변수임을 알 수 있었다.

다음으로 모형 비교 기준인 AIC(Akaike Infor- 
〈표 4〉모형 비교(Model Comparison)

\begin{tabular}{|c|c|c|c|c|}
\hline & $\begin{array}{l}\text { 전체 모형 } \\
\text { Model I }\end{array}$ & $\begin{array}{c}\text { 표적 시장 제품 } \\
\text { 확산 정보 제거 } \\
\text { Model II }\end{array}$ & $\begin{array}{c}\text { 타 시장 제품 확산 } \\
\text { 정보 제거 } \\
\text { Model III }\end{array}$ & $\begin{array}{c}\text { 가격 효과 제거 } \\
\text { Model IV }\end{array}$ \\
\hline $\begin{array}{c}\text { 표적 시장의 } \\
\text { 평균 혁신 계수 }\end{array}$ & $\begin{array}{c}29.4317 * * \\
(14.720)\end{array}$ & & $\begin{array}{l}18.7177 \\
(16.397)\end{array}$ & $\begin{array}{l}33.6932 \\
(13.557)\end{array}$ \\
\hline $\begin{array}{c}\text { 표적 시장의 } \\
\text { 평균 모방 계수 }\end{array}$ & $\begin{array}{l}1.2259 \\
(1.674)\end{array}$ & & $\begin{array}{l}-0.6866 \\
(1.776)\end{array}$ & $\begin{array}{l}1.7739 \\
(1.784)\end{array}$ \\
\hline $\begin{array}{c}\text { 대상 제품의 타 시장 } \\
\text { 평균 혁신 계수 }\end{array}$ & $\begin{array}{l}36.1888^{* * *} \\
(13.710)\end{array}$ & $\begin{array}{c}33.2419 * * \\
(12.602)\end{array}$ & & $\begin{array}{c}29.6437^{* *} \\
(11.534)\end{array}$ \\
\hline $\begin{array}{c}\text { 대상 제품의 타 시장 } \\
\text { 평균 모방 계수 }\end{array}$ & $\begin{array}{l}1.4212 \\
(1.245)\end{array}$ & $\begin{array}{l}1.5580 \\
(1.255)\end{array}$ & & $\begin{array}{c}2.9654^{* *} \\
(1.028)\end{array}$ \\
\hline 디스플레이 종류 & $\begin{array}{l}0.8152^{*} \\
(0.485)\end{array}$ & $\begin{array}{l}0.7629 \\
(0.493)\end{array}$ & $\begin{array}{l}0.4568 \\
(0.395)\end{array}$ & $\begin{array}{l}0.6877 \\
(0.472)\end{array}$ \\
\hline 디스플레이 인치 & $\begin{array}{c}0.0702 * * \\
(0.028) \\
\end{array}$ & $\begin{array}{c}0.0702^{* *} \\
(0.027) \\
\end{array}$ & $\begin{array}{c}0.0577^{* *} \\
(0.022) \\
\end{array}$ & $\begin{array}{l}0.0309 \\
(0.019) \\
\end{array}$ \\
\hline 제품 가격 & $\begin{array}{l}-2.7 \mathrm{E}-05^{* *} \\
(1.062 \mathrm{E}-05)\end{array}$ & $\begin{array}{c}-3 \mathrm{E}-05^{* *} \\
(1.040 \mathrm{E}-05)\end{array}$ & $\begin{array}{l}-2.4 \mathrm{E}-05^{* *} \\
(8.504 \mathrm{E}-06)\end{array}$ & \\
\hline $\begin{array}{c}\text { 시장 가격 대비 } \\
\text { 대상 제품 가격 비율 }\end{array}$ & $\begin{array}{c}0.2927^{* * *} \\
(0.111)\end{array}$ & $\begin{array}{l}0.2917^{* *} \\
(0.111)\end{array}$ & $\begin{array}{c}0.2812^{* *} \\
(0.103)\end{array}$ & \\
\hline $\begin{array}{c}\text { 전기 } \\
\text { 누적판매량 }\end{array}$ & $\begin{array}{l}4.02 \mathrm{E}-05^{* * *} \\
(1.176 \mathrm{E}-05)\end{array}$ & $\begin{array}{l}3.63 \mathrm{E}-05^{* *} \\
(1.186 \mathrm{E}-05)\end{array}$ & $\begin{array}{l}4.27 \mathrm{E}-05^{* *} \\
(1.337 \mathrm{E}-05)\end{array}$ & $\begin{array}{l}3.05 \mathrm{E}-05^{* *} \\
(8.932 \mathrm{E}-06)\end{array}$ \\
\hline $\begin{array}{l}-2 \mathrm{LL} \\
\end{array}$ & 597.0333 & 600.7396 & 620.677 & 606.0379 \\
\hline AIC & 615.0333 & 614.7396 & 634.677 & 620.0379 \\
\hline $\mathrm{BIC}$ & 653.1253 & 644.3667 & 664.3041 & 649.665 \\
\hline
\end{tabular}

() 표준 편차

* 유의수준 $10 \%$ 이하

** 유의 수준 $5 \%$ 이하

mation Criteria)와 $\mathrm{BIC}$ (Bayesian Information Criteria)를 기준으로 표적 시장의 타 제품 확산 정보, 대상 제품의 타 시장 확산 정보, 제품 속 성, 가격의 매출 이륙 시점 예측에 필요한 상대 적 중요도를 〈표 4〉와 같이 평가하였다. 4 가지 모형 중 표적 시장에서 타 제품의 평균 확산 정보를 제거한모형(Model 2)이 $\mathrm{AIC}$ 나 $\mathrm{BIC}$ 기
준으로 볼 때 가장 나은 성과를 보였다. 즉, 대 상 제품의 타 시장 매출 확산 정보를 이용하는 것이 표적 시장의 확산 정보 보다 표적 시장의 매출 이륙 시점을 예측하는데 더 유용하다는 것을 알 수 있었다. 4 가지 모형 중 가장 낮은 성과를 보인 것은 대상 제품이 타 시장에서 보 인 매출 확산 정보를 고려하지 않은 모형 III이 
었다. 전체적으로 매출 이륙 시점 예측 시 적어 도 표적 시장의 확산 성향보다는 가격 정보 특 히 시장 가격 대비 대상 제품 가격 비율이 더 중요함을 알 수 있다. 결국, 본 연구에서 고려 하는 주요 설명 변수 즉 제품 속성 변수, 제품 의 타 시장 확산 정보, 표적 시장의 확산 정보 중 가장 매출 이륙 시점 예측에 중요한 변수는 제품의 타 시장 성과 변수임을 알 수 있었다. ${ }^{3)}$

결국, 4 가지 모형 비교 결과를 토대로 이륙 시점의 발생시기에 유의하게 영향을주는 변수 들만을 고려한 최적 모형을 이용하여 예측 모 형이 실제 어느 정도의 예측력을 보이는 지를 검사하였다. 분석 결과를 종합해 보면, 제품 속 성 중에서는 디스플레이 크기, 관심 제품의 타 시장 평균 혁신 성향, 제품의 가격변수는 제품 가격과 시장 가격 대비 제품 가격 비율 모두가 대상 제품의 이륙 시점 설명에 주요한 역할을 함을 알 수 있었다. 4 가지 모형 비교 결과를 토 대로 이륙시점의 발생시기에 가장 영향을 주는 변수들을 고려한 최적 모형을 결정하였는 데 최적 모형의 분석 결과를 보면 아래〈표 5〉와 같다.

〈표 5〉 모형 적합성

\begin{tabular}{|c|c|c|}
\hline 모형 & AIC & BIC \\
\hline 최적 모형 & 592.8736 & 621.8735 \\
\hline
\end{tabular}

기업의 입장에서 실질적으로 매출 이륙 시점 을 예측하고자 하는 시점은 각각 다를 수 있다. 모형의 예측력 역시, 예측하는 시점에 따라 다
를 수 있으므로, 모형의 예측력을 예측하고자 하는 각 시점 별로 비교 평가해 보고자 한다. 일반적으로 기업의 입장에서 매출 이륙 시점을 알고 싶은 경우는 표적 시장에 진출 전, 또는 이미 진출한 경우에는 매출 이륙이 발생하지 않은 시점일 것이다. 때문에 매출 예측을 시도 하는 시점을 매출이 전혀 발생하지 않은 시점 인 출시 전 시점 ${ }^{4}$ 부터 실제 매출 이륙이 벌어 지기 직전 시점까지 모형의 매 기별 예측 성과 를 평가해 보았다. 시장과 제품별로 매출 이륙 시점이 빠르면 3개월째부터 발생하여 보통 6기 (개월)이내에 매출 이륙이 발생하였으므로 예 측 시점은 0 기(제품 출시 전)부터 5 기(개월)까 지 각 기(월)별로 최적 모형의 예측력을 평가 해 보았다. 즉, 전체 매출 자료 중 제품별로 $74 \%$ 에 해당하는 시장 매출 자료를 이용하여 모형 추정(model estimation)을 하였고, 나머지 $26 \%$ 에 해당하는 유보 표본(hold-out sample) 자료를 이용하여 예측력(out-of-sample fit)을 분석하였다. 본 모형을 적용 시 예측력을 어느 정도 향상시킬 수 있는 지를 보기 위해 다음 두 가지 모형과의 예측력 비교 분석을 하였다. 첫 번째 비교 모형은 예측하고자 하는 시기 이 후의 각 시점 중 평균적으로 가장 매출 이륙이 많이 나타난 시점을 매출 이륙 시점으로 예측 하는 평균 모형을 선택하였다. 이 경우 모형이 예측한 매출 이륙 시점은 예측하는 시기에 따 라 변동한다. 왜냐하면 매출 이륙 시점이 예측 하고자 하는 시기 이전에 발생한 경우를 매번 제거하고 나머지 자료를 이용하여 평균적으로

3) 실증 분석 결과를 해석하는 데 있어 중요한 지적을 해 주신 심사자께 감사드립니다.

4) 이 경우에는 최적 모형에서 설명 변수인 시장평균 가격 대비 대상 제품 가격 비율 변수를 사용할 수 없으므로 이 변수 를 제외한 설명 변수를 이용하여 분석하였다. 
가장 매출 이륙이 많이 벌어진 시기를 계산하 기 때문이다. 이 모형은 특별한 모형을 개발하 지 않아도 해외 여러 나라의 매출 자료가 존재 하면 쉽게 계산해 낼 수 있는 방법으로 모형 예측력 평가의 기준치로 계산해 보았다. 최적 모형과의 두 번째 비교 모형은 본 연구에서 제 시하고 있는 모형이나 설명 변수를 일반적으로 해외 복수 시장의 정보를 이용할 수 없는 경우 로 한정한 모형이다. 즉, 예측 모형이 가장 일 반적으로 많이 고려하는 제품 속성, 가격, 매출 정보만을 고려한 모형으로 이 모형에서 해외 복수 시장의 정보를 이용한 경우 예측력과의 비교를 시도하였다.

최적 모형과 두 비교 대상 모형의 예측력 결 과)는 다음 〈그림 5〉와 같다.

전체적으로 최적 모형의 예측력은 어느 시점
에서나 일반 모형과 평균 모형에 비해 향상된 것으로 나타났다. 특히, 평균 모형과 비교할 때 최적 모형을 적용한 경우 예측력이 최소 $12.5 \%$ 서 최대 $55.6 \%$ 까지 향상되었다.

평균 모형에 비해 예측력 증가율이 큰 시기는 $2,3,4$ 번째 매출이 벌어진 시기로 최적 모형이 평균 모형 대비 예측력이 모두 $50 \%$ 이상 향상 되었다. 반면에 4 기 이후 예측력의 차이가 급격 하게 떨어져 5 기 이후에는 모형간의 차이가 크 지 않음을 알 수 있다. 즉, 본 연구에서 제시하 는 모형은 TV의 경우 매출 이륙 시점을 예측 하는 시점이 4 기 이전인 경우에 유용함을 알 수 있었다. 반면에 4 기를 넘어가면 평균 모형을 이용하거나 최적 모형을 이용하거나 예측능력 에 큰 차이가 없음을 알 수 있다. 특히 2기 이 후부터 매출 이륙 시점 예측에서 최적 모형이

〈그림 5〉

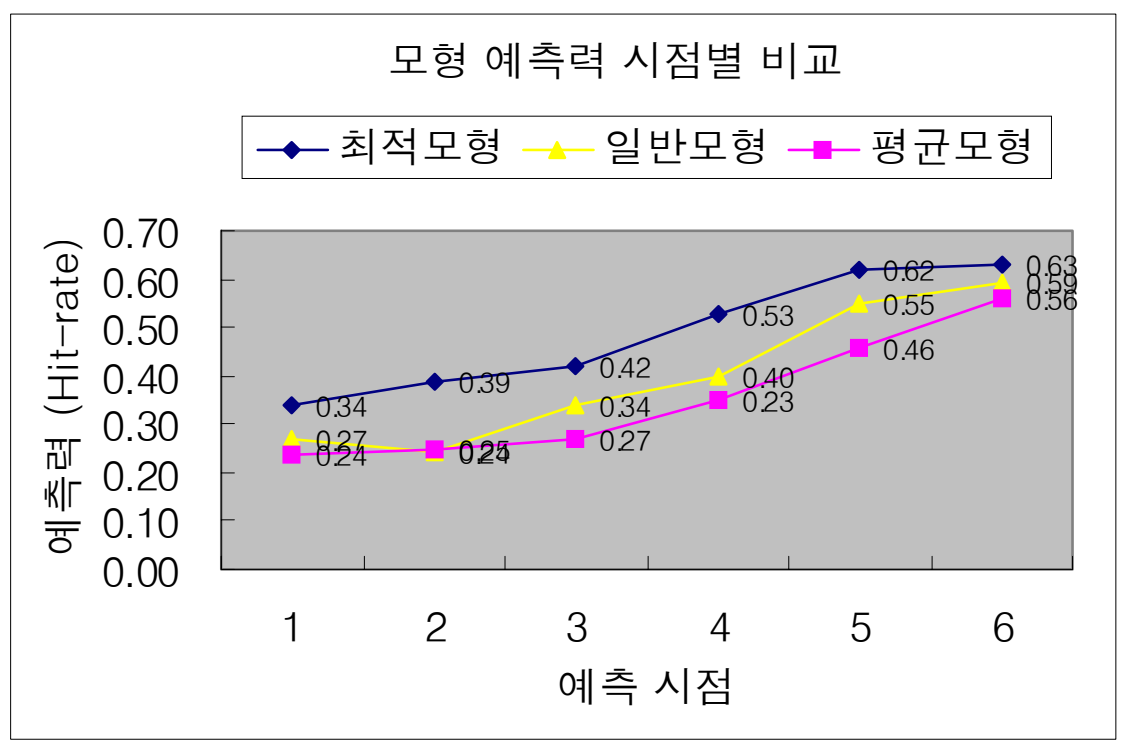

5) 시점별 모형 예측력 평가는 matlab 13.0 을 이용하여 처리하였다. 
높은 성과를 보여 주었는 데, 이는 0기 시점에 서의 예측에서 이용하지 못한 매출 변수와 가 격 변수가 점차 중요한 역할을 하였기 때문이 라고 판단된다. 3 기 이후 5 기까지 시점에서의 매출 이륙 시점 예측력은 지속적으로 향상되었 으나 시기가 지남에 따른 정확도 개선은 그리 크지 않은 것으로 나타났다.

\section{V. 결론 및 향후 연구 방향}

본 연구는 해외 여러 시장에서 제품을 판매하 는 글로벌 기업의 입장에서 자사 제품이 각 시 장에서 발생하는 매출 이륙 시점을 예측할 수 있는 모형을 개발하였다. 해외 시장에서 발생한 $\mathrm{TV}$ 매출 자료에 이 모형을 적용하여 매출 이 륙 시점을 예측하여 보았고, 복수 시장에서 자 사 제품의 매출 이륙 시점을 예측하는 데 유용 한 설명 변수가 무엇인지를 탐색적 분석을 통 해 알아 보았다. 즉, 매출 이륙 시점을 예측하 는 데 표적 시장에서의 타 제품 확산 정보, 대 상 제품의 타 시장 확산 정보, 시장 가격 대비 대상 제품의 가격 비율, 제품 속성, 그리고 전 기까지의 매출액 등이 이륙 시점에 어떠한 영 향을 미치는 지를 분석하였다.

실증 분석 결과, 실증 분석을 통해 매출 이륙 시점 예측에 유용한 변수들을 다음과 같이 파 악할 수 있었다. 첫째, 대상 제품이 표적 시장 에 진출하기 이전에 진출한 타 시장에서의 매 출자료를 표적 시장에서의 대상 제품 매출 이 륙 시점 예측에 이용하는 것이 매우 유용함을 실증 분석을 통해 알 수 있었다. 대상 제품의
타 시장에서의 확산 정보 중 혁신 성향 계수가 이륙 시점 예측에 매우 중요함을 알 수 있었다. 즉, 매출 이륙 시점이 시장의 모방 성향보다는 혁신 성향에 의해 크게 좌우된다는 점을 알 수 있었다. 글로벌 기업들의 경우, 특정 국가의 시 장 매출 이륙 시점 예측을 위해 여러 다른 나 라의 시장 매출 자료를 활용할 필요가 있음을 알 수 있다. 둘째, 타 제품의 표적 시장 판매 자료는 예상과 달리 대상 제품의 표적 시장에 서의 매출 이륙 시점 예측에 기여도가 낮음을 알 수 있었다. 즉, 표적 시장에서 다른 제품들 이 평균적으로 어떻게 판매되었는지 (확산 정 보) 보다는 대상 제품이 다른 시장에서 어떻게 판매되었는지(확산 정보)를 아는 것이 대상 제 품의 표적 시장에서의 매출 이륙 시점을 예측 하는 데 효과적임을 밝힐 수 있었다. 셋째, 일 반적 인식처럼 가격과 제품의 속성도 이륙시점 의 발생 시기에 영향을 미치는 것을 알 수 있 었다. 하지만 제품의 자체 가격 정보 보다 시장 평균 가격 대비 대상 제품 가격 비율이 매출 이륙 시점 예측에 보다 효과적임을 알 수 있었 다. 시장 평균 가격 대비 대상 제품 가격 비율 은 본 연구에서 고려하는 제품 수준의 연구에 서 이용할 수 있는 주요 변수인 반면에 기존 시장/산업 수준의 제품 생명 주기 상 매출 이 륙 시점 연구에서는 사용할 수 없는 변수이기 에 중요한 결과라고 판단된다. 마지막으로, 전 기 누적 매출량 역시 $\mathrm{plc}$ 중 초기 시점을 예측하 는 상황임에도 불구하고 제품 수준의 매출 이 륙 시점에 영향을 미치는 것을 알 수 있었다.

본 연구에서 제시한 매출 이륙 시점 예측 모 형은 평균치에 근거한 일반적 예측과 비교해 볼 때 높은 예측력을 보여 주었다. 평균치에 근 
거한 일반적 예측에 비해 예측력 개선의 정도 는 시기별로 달랐는데, 평균 모형에 비해 예측 력 증가율이 가장 큰 시기는 2 번째 매출이 벌 어진 시기로 최적 모형의 예측력이 평균 모형 대비 $59.26 \%$ 향상되었다. 반면에 4 기 이후 모 형간 예측력의 차이는 급격하게 떨어져 큰 차 이를 보이지 않음을 알 수 있다. 매출 이륙 시 점을 언제 예측하는 것이 바람직한 것인가 하 는 관점에서 보면, 매출 이륙 시점 예측은 제품 출시 후 시간이 지날 수록 이용 가능한 정보가 증가하므로 매출 이륙 시점의 예측력이 높아지 나 본 연구에서 제시한 모형의 상대적 기여도 측면에서 본 다면, 특히 예측 시점이 2 기일 때 본 모형이 효과적임을 알 수 있었다.

본 연구 결과가 기여하는 바는 크게 다음 세 가지를 들 수 있다. 첫째, 기존 확산모형이 주 로 생명 주기 중 주로 변곡 시점 이후의 매출 을 예측하는 데 주력한 반면, 본 연구에서는 제 품의 이륙 시점을 측정하고, 예측하는 모형을 제시하였다. 둘째, 기존 연구들이 단일 시장 수 준의 확산을 연구한 반면, 본 연구는 글로벌 시 장에서 적용 가능한 제품 수준의 매출 이륙 시 점을 예측할 수 있는 모형을 제시할 수 있었다. 특히 타 시장에서의 대상 제품 확산 정보를 이 용하는 것이 전기 매출 자료나 표적 시장에서 의 타 제품 매출 자료를 이용하는 것 보다 유 용하다는 분석 결과는 글로벌 기업들의 입장에 서 보다 정교한 모형을 개발할 수 있는 방향을 제시하였다고 본다. 셋째, 매출 이륙 시점 예측 모형의 예측력은 실제로 예측 시점이 언제인지 에 따라 달라지는 데 기존 연구와 달리 본 연 구에서는 처음으로 매출 이륙 시점 예측력을 예측 시점 별로 분석하여 모형의 예측력을 이
해하는 데 새로운 접근법을 제시하였다. 하지만 본 연구는 다음과 같은 한계를 가지고 있으며, 이를 극복하기 위해 앞으로 필요한 연구 방향 을 제시하면 다음과 같다. 첫째, 본 연구에서는 비교적 여러 제품에 대해 다양한 국가의 시장 자료를 토대로 실증 분석을 하였으나, 제품이 $\mathrm{PDP} \mathrm{TV}$ 와 LCD TV에 한정되어 있어 실증 분석결과를 일반화 하는데 한계를 가지고 있다. 향후에 다양한 제품군을 대상으로 매출 이륙 시점 예측 연구가 진행되어야 할 것이다. 둘째, 이륙 시점 예측 능력을 향상시키기 위해 보다 다양한 변수를 추가적으로 고려하는 모형의 연 구가 진행되어야 할 것이다. 특히 경쟁 제품의 매출이나 가격 변화가 대상 제품의 매출 이륙 시점에 미치는 영향을 고려한 모형을 개발하는 것은 중요한 연구 과제라고 판단된다. 특정 제 품의 매출 이륙 시점이 경쟁사 제품의 매출 이 륙 시점과 어떤 관계를 갖는 지를 아는 것도 매우 흥미로운 주제라고 판단된다. 셋째, 매출 이륙 시점을 측정하는 여러 방법 중 어떤 방법 이 보다 적합한지에 대한 연구가 필요하다. 매 출 이륙 시점 예측에 앞서서 보다 정확한 매출 이륙 시점을 알아내는 것은 중요한 과제이나 아직 다루어지지 않은 연구 분야이다. 더 나아 가, 매출 이륙 시점 측정 방법의 결정이 매출 이륙 시점 예측 모형의 예측력에 어떤 영향을 미치는 지를 평가하는 연구가 필요하다. 마지막 으로, 본 연구는 이륙시점을 예측하는 데 주력 하였으나, 향후에는 제품수명주기 상에 존재하 는 다른 주요 시점 즉, 변곡 시점, 그리고 쇠퇴 시점에 대한 예측 모형이 개발되어야 할 것이 다. 이러한 연구가 향후 활발히 진행된다면, 글 로벌 기업이 언제, 어느 시장에서 어느 제품에 
대한 마케팅 활동을 집중해야 할 지에 대한 의 사 결정을 하는 데 많은 도움을 줄 수 있을 것 이라고 판단된다.

〈논문 접수일: 2007. 10. 24〉

〈게재 확정일: 2008. 01. 30〉

\section{참고문헌}

Bass, Frank M.(1969), “A new product growth model for consumer durables," Management Science, 15(January) 215-227

Cox, D. R.(1972), "Regression models and life tables," Journal of the Royal statistical Society, 34, 187-202.

Efron, Bradley(1977), "The efficiency of Cox's likelihood function for censored data," Journal of the American Statistical Association, 72 , 557-565.

Eitan Muller and Guy Yogev(2006), "When Does the Majority Become a Majority? Empirical analysis of the time at which main market adopters purchase the bulk of our sales," Technological Forecasting and Social Change, 73, 1107-1120.

Gatignon, Hubert, Joshua Eliashberg, Thomas S. Robertson,(1989), "Modeling multinational diffusion patterns: An efficient methodology," Marketing Science, Vol. 8, No. 3, 231-247 Golder, N. Peter(1994), "Beyond Diffusion: An Explanatory Model of The Take-off and Growth of Sales for Consumer Duralbles,"
University of Southern California, Doctoral dissertation. and Gerard J. Tellis(1997), "Will It Ever Fly? Modeling the Takeoff of Really New Consumer Durables," Marketing Science, Vol. 16, No.3, 256-270. and (1998),

"Beyond Diffusion: An Affordability Model of the Growth of New Consumer Durables,"Journal of Forecasting, 17, 259-280. and (2004),

"Growing, Growing, Gone: Cascades, Diffusion, and Take-off Points in the Product Life Cycle”, Marketing Science, Vol. 23, No. 2 (Spring), 207-218.

Hauser, John, Gerard J. Tellis and Abbie Griffin,(2006), "Research on Innovation: A Review and Agenda for Marketing Science," Marketing Science, Nov/Dec, Vol. 25 Issue 6, 687-717.

Kalish, Shlomo, Vijay Mahajan and Eitan Muller (1995), "Waterfall and Sprinkler NewProduct Strategies in Competitive Global Markets," International Journal of Research in Marketing, Vol. 12, Issue 2, (July), Page 105-119.

Kalis, Shlomo and Gary L, Lillien(1986), "A Market Entry Timing Model for New Technologies," Management Science, 32(February), 194-205.

Mahajan, Vijay, Eitan Muller, Frank M. Bass (1990), "New product diffusion models in marketing: A review and directions for 
research," Journal of Marketing, 54 (January), 1-26.

Yoram Wind,

(2000), "New-product diffusion models:

From theory to practice," New-Product Diffusion Models, Vijay Mahajan, Eitan Muller, Yoram Wind, eds. Kluwer Academic Publishers, Bostern, MA.

Marketing Science Institute(1995), Research

Priorities, Boston, MA: Marketing Science Institute

Meade, Migel and Towhidul Islam(1998), "Technological Forecasting - Model selection and estimation for technological growth curves," Management Science, Vol 44, No. 8. 1115-1130.
Rogers, Everett M.(1983)," Diffusion of Innovations," $3^{\text {rd }}$ ed. New York: The Free Press. Talukdar, Debabrata, K. Sudhir, and Andrew Ainslie(2002), "Investigating New Product Diffusion Across Products and Countries," Marketing science, Vol. 21 No. 1, 97-114. Takada, Hirokazu and Dipak Jain(1991), "CrossNational Analysis of Diffusion of Consumer Durable Goods in Pacific Rim Countries," Journal of Marketing, Vol. 55 (April), 48-54.

Tornatzky, L. G and R. J. Klein(1982), "Innovation Characteristics and Innovation AdoptionImplementation: A Meta-Analysis of Findings," IEEE Transaction on Engineering Management, EM-29, 28-45 


\title{
An Exploratory Study on Forecasting Sales Take-off Timing for Products in Multiple Markets*
}

\author{
Chung, Jaihak ${ }^{* *}$ \\ Chung, Hokyung***
}

\begin{abstract}
The objective of our study is to provide an exploratory model for forecasting sales take-off timing of a product in the context of multi-national markets. We evaluated the usefulness of key predictors such as multiple market information, product attributes, price, and sales for the forecasting of sales take-off timing by applying the suggested model to monthly sales data for PDP and LCD TV provided by a Korean electronics manufacturer.

We have found some important results for global companies from the empirical analysis. Firstly, innovation coefficients obtained from sales data of a particular product in other markets can provide the most useful information on sales take-off timing of the product in a target market. However, imitation coefficients obtained from the sales data of a particular product in the target market and other markets are not useful for sales take-off timing of the product in the target market. Secondly, price and product attributes significantly influence on take-off timing. It is noteworthy that the ratio of the price of the target product to the average price of the market is more important than the price ofthe target product itself. Lastly, the cumulative sales of the product are still useful for the prediction of sales take-off timing. Our model outperformed the average model in terms of hit-rate.
\end{abstract}

Key words: Take-off timing, PLC(Product Life Cycle), Bass Model, Diffusion, Global Markets, Hazard model

\footnotetext{
* We are grateful for the suggestions and helps from two anonymous reviewers

* The School of Business Administration, Sogang University Associate Professor(jaihak@sogang.ac.kr)

*** Daelim Industrial Co., Ltd.(hkjung@sogang.ac.kr)
} 
The objective of our study is to provide a forecasting model for sales take-off timing of a product sold in multi-national markets. Forecasting sales take-off timing of a product has little been studied in the marketing literature while field managers regard the forecasting of sales take-off timing of products as the most important task for PLC-based planning.

We employed Cox proportional hazard model to develop a forecasting model for sales takeoff timing and considered five types of predictors: (1) Information on the previous diffusion of target products in other markets, (2) Information on the diffusion of other products in the target market, (3) the attribute of target products, (4) the price of target products, and
(5) the cumulative sales of target products in the target markets. There are three different methods for the measurement of take-off timing in the extant studies. We used one of them, called Maximum Growth Rule, to measure the response variable, the take-off time of a product.

We evaluated the usefulness of each predictor for the forecasting of sales take-off timing by applying the model to monthly sales data between January 2003 to May 2006 for ninety products (PDP and LCD TV) sold in 10 different countries by a Korean electronics manufacturer. The following histogram shows the distribution of sales take-off times of ninety products in the dataset.

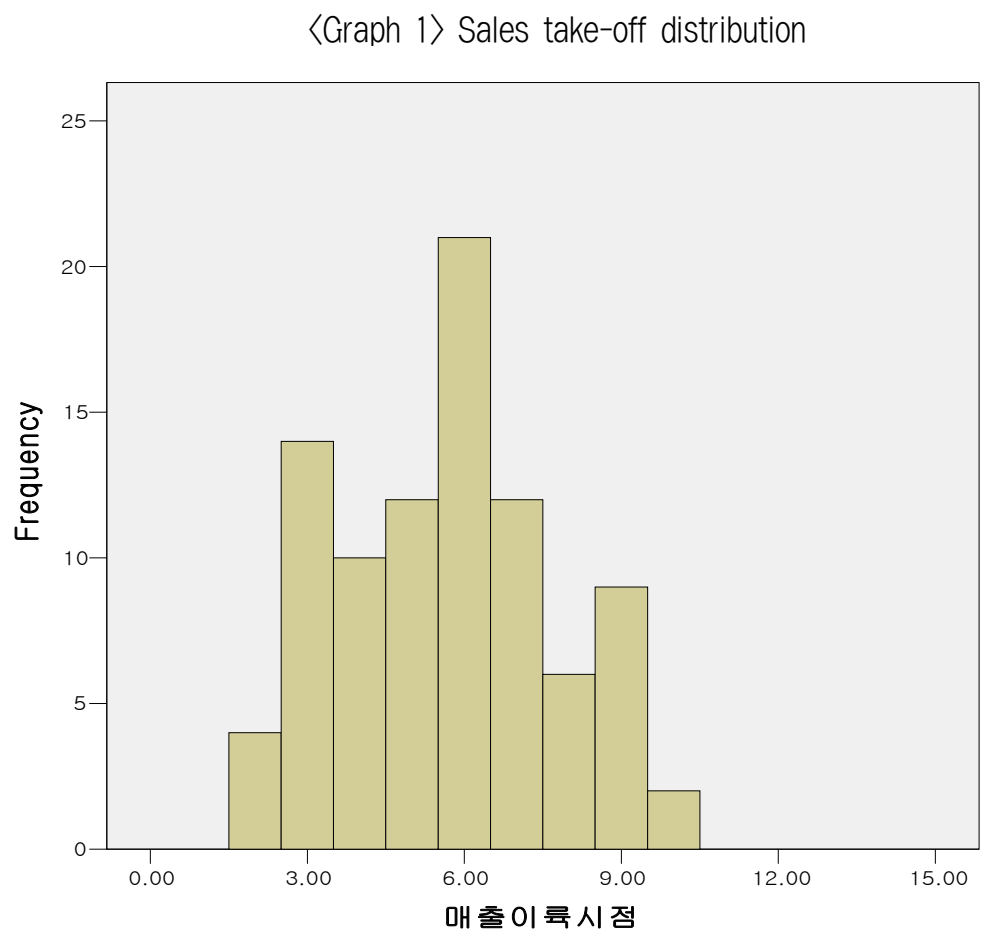

해외 복수 시장 진출 기업의 제품 매출 이륙 시점 예측 모형에 관한 연구 25 
The average take-off time of this sample is 5.66 (months) and its standard deviation is 2.07, which means the variety of the take-off times of products over countries. Most of take-off times are within 3 to 9 months.

We estimated the model with this dataset and suggest the best model as below.

The results of the significant tests of five types of predictors show that product attributes are useful predictors, especially the size of TV monitor. It is not surprising that price predictors are useful. Especially, ratio of the price of a target product and market average price is more important than the price of a target product itself. This variable has not been introduced as a predictor for forecasting take- off times in the extant studies but our study show the usefulness of a new predictor.

One of the most important questions in this research is whether we can use the diffusion data of a target product in other markets and the diffusion data of other products in the target market for global firms launching and selling products in multiple markets. These variables are especially important to global firms since only global firms can obtain and use such information. To test the usefulness of these two types of predictors, we implemented model comparison by estimatingfour models with different predictors: (1) model I (full model) with all predictors considered in this study, (2) model II without predictors of market diffusion of other products in target markets, (3) model III without predictors of market diffusion of target products in other markets, and (4) model IV without predictors of market price.

The results of this model comparison shows that, among information on market diffusion, innovation coefficients of the target products in other markets are important predictors, while imitation coefficients are not significant predictors, for forecasting sales take-off times. This result implies that sales take-off time depends on the innovativeness of the market.

$\langle$ Table 1〉 The parameter estimates of Best model

\begin{tabular}{|c|c|c|c|}
\hline & Estimate means & S.E. & P-value \\
\hline Display Size (Inch) & 0.044736 & 0.0134 & 0.001 \\
\hline $\begin{array}{c}\text { Average Innovation Coefficient of a } \\
\text { target product in other markets }\end{array}$ & 34.31172 & 5.8012 & 0.000 \\
\hline Product Price & $-3.1 \mathrm{E}-05$ & $8.89 \mathrm{E}-06$ & 0.001 \\
\hline $\begin{array}{c}\text { Ratio of the price of the target } \\
\text { product and market average price }\end{array}$ & 0.328341 & 0.1090 & 0.003 \\
\hline $\begin{array}{c}\text { Cumulative sales of the target } \\
\text { product }\end{array}$ & 0.000035 & $1.18 \mathrm{E}-05$ & 0.003 \\
\hline
\end{tabular}

\section{6 한국마케팅저널 제10권 제2호 2008년 7월}


Furthermore, we tested the predictive power of the model suggested in the study. Since the predictive power of the model varies over the time of prediction while some firms need to predict the sales take-off time before launching their product, while other firms need to predict that three months after launching the product. We estimated the best model with $74 \%$ of sales data and tested the out-of sample fits of these models with the rest of sales data (holdout sample). In order to understand how much the suggested model improve the prediction accuracy compared to other methods, we tested two more models: (1) average model which predicts sales take-off time based on averaged take-off times obtained from the dataset and (2) another model suggested in this study without some predictors of market diffusion. The best model outperformed average model, which can be regarded as a base model for firms which have no other method for forecasting sales take-off times, by from $12.5 \%$ to $55.6 \%$.

We have found some important results for global companies from the empirical analysis. Firstly, innovation coefficients obtained from sales data of a particular product in other markets can provide the most useful information on sales take-off timing of the product in a target market. However, imitation coefficients obtained from the sales data of a particular product in the target market and other markets are not useful for sales take-off timing of the product in the target market. Secondly, price and product attributes significantly influence on take-off timing. It is noteworthythat the ratio of the price of the target product to the average price of the market is more important than the price of the target product itself. Lastly, the cumulative sales of the product are still useful for the prediction of sales take-off timing. Our model outperformed the average model in terms of hit-ratio.

Our study makes some contributions to the PLC literature. Firstly, the model suggests in the study is the first one for forecasting of sales take-off of a product sold in multiple markets. Secondly, we found a new useful predictor, sales diffusion of a target product in other markets, which can be used for firms selling products in multiple markets/countries. Lastly, the study implemented out-of-sample fit tests with different prediction time which has never been considered in the marketing literature.

\section{Reference}

Bass, Frank M.(1969), “A new product growth model for consumer durables," Management Science, 15(January) 215-227

Cox, D. R.(1972), "Regression models and life tables," Journal of the Royal statistical Society, 34, 187-202.

Efron, Bradley(1977), "The efficiency of Cox's 
likelihood function for censored data," Journal of the American Statistical Association, 72 , 557-565.

Eitan Muller and Guy Yogev(2006), "When

Does the Majority Become a Majority? Empirical analysis of the time at which main market adopters purchase the bulk of our sales," Technological Forecasting and Social Change, 73, 1107-1120.

Gatignon, Hubert, Joshua Eliashberg, Thomas S. Robertson,(1989), "Modeling multinational diffusion patterns: An efficient methodology," Marketing Science, Vol. 8, No. 3, 231-247

Golder, N. Peter(1994), "Beyond Diffusion: An Explanatory Model of The Take-off and Growth of Sales for Consumer Duralbles," University of Southern California, Doctoral dissertation.

and Gerard J. Tellis(1997), "Will It Ever Fly? Modeling the Takeoff of Really New Consumer Durables," Marketing Science, Vol. 16, No.3, 256-270. and (1998),

"Beyond Diffusion: An Affordability Model of the Growth of New Consumer Durables," Journal of Forecasting, 17, 259-280. and (2004),

"Growing, Growing, Gone: Cascades, Diffusion, and Take-off Points in the Product Life Cycle”, Marketing Science, Vol. 23, No. 2 (Spring), 207-218.

Hauser, John, Gerard J. Tellis and Abbie
Griffin,(2006), "Research on Innovation: A Review and Agenda for Marketing Science," Marketing Science, Nov/Dec, Vol. 25 Issue 6, 687-717.

Kalish, Shlomo, Vijay Mahajan and Eitan Muller (1995), "Waterfall and Sprinkler NewProduct Strategies in Competitive Global Markets," International Journal of Research in Marketing, Vol. 12, Issue 2, (July), Page 105-119.

Kalis, Shlomo and Gary L, Lillien(1986), "A Market Entry Timing Model for New Technologies," Management Science, 32(February), 194-205.

Mahajan, Vijay, Eitan Muller, Frank M. Bass (1990), "New product diffusion models in marketing: A review and directions for research," Journal of Marketing, 54(January), $1-26$. Yoram Wind, (2000), “New-product diffusion models: From theory to practice,"New-Product Diffusion Models, Vijay Mahajan, Eitan Muller, Yoram Wind, eds.. Kluwer Academic Publishers, Bostern, MA.

Marketing Science Institute(1995), Research Priorities, Boston, MA: Marketing Science Institute

Meade, Migel and Towhidul Islam(1998), "Technological Forecasting - Model selection and estimation for technological growth curves," Management Science, Vol 44, No. 8. 1115-1130. 
Rogers, Everett M.(1983)," Diffusion of Innovations," $3^{\text {rd }}$ ed. New York: The Free Press.

Talukdar, Debabrata, K. Sudhir, and Andrew Ainslie(2002), "Investigating New Product Diffusion Across Products and Countries," Marketing science, Vol. 21 No. 1, 97-114.

Takada, Hirokazu and Dipak Jain(1991), "CrossNational Analysis of Diffusion of Consumer
Durable Goods in Pacific RimCountries," Journal of Marketing, Vol. 55 (April), 4854.

Tornatzky, L. G and R. J. Klein(1982), "Innovation Characteristics and Innovation AdoptionImplementation: A Meta-Analysis of Findings," IEEE Transaction on Engineering Management, EM-29, 28-45 